\title{
Optimisasi Multi-objektif pada Rekonfigurasi Jaringan Distribusi Tenaga Listrik dengan Integrasi Pembangkit Terdistribusi Menggunakan Metode Sistem Kekebalan Buatan
}

\author{
Ramadoni Syahputra ${ }^{1}$ dan Indah Soesanti ${ }^{2}$ \\ ${ }^{1}$ Program Studi Teknik Elektro, Fakultas Teknik, Universitas Muhammadiyah Yogyakarta \\ Jl. Brawijaya, Tamantirto, Kasihan, DI Yogyakarta, 55183, Indonesia \\ ${ }^{2}$ Departemen Teknik Elektro dan Teknologi Informasi, Fakultas Teknik, Universitas Gadjah Mada \\ Jl. Grafika 2, Kampus UGM, Yogyakarta, 55281, Indonesia \\ ramadoni@umy.ac.id ${ }^{1}$,indahsoesanti@ugm.ac.id ${ }^{2}$
}

\begin{abstract}
This study proposes a multi-objective optimization for power distribution network reconfiguration by integrating distributed generators using an artificial immune system (AIS) method. The most effective and inexpensive technique in reducing power losses in distribution networks is optimizing the network reconfiguration. On the other hand, small to medium scale renewable energy power plant applications are growing rapidly. These power plants are operated on-grid to a distribution network, known as distributed generation (DG). The presence of DG in this distribution network poses new challenges in distribution network operations. In this study, the distribution network optimization was carried out using the AIS method. In optimization, the goal to be achieved is not only one objective but should be multiple objectives. Mul ti-objective optimization aims to reduce power losses, improve the vol tage profile, and maintain a maintained network load balance. The AIS method has the advantage of fast convergence and avoids local minima. To test the superiority of the AIS method, the distribution network optimization with and without DG integration was carried out for the 33-bus and 71-bus models of the IEEE standard distribution networks. The results show that the AIS method can produce better system operating conditions than before the optimization. The parameters for the success of the optimization are minimal active power losses, suitable vol tage profiles, and maintained load bal ance. This optimization has successfully increased the efficiency of the distribution network by an average of $0.61 \%$.
\end{abstract}

Keywords- multi-objective optimization, network reconfiguration, distribution network, distributed generation, artificial immune system

Abstrak- Penelitian ini mengusulkan optimisasi multi-objektif pada rekonfigurasi jaringan distribusi tenaga listrik dengan integrasi pembangkit terdistribusi menggunakan metode sistem kekebalan buatan (SKB). Teknik paling efektif dan murah dalam mereduksi rugi-rugi daya jaringan distribusi adalah dengan optimisasi konfigu rasi jaringan. Di sisi lain, perkembangan pembangkit listrik energi terbarukan skala kecil hingga menengah semakin pesat. Pembangkit-pembangkit listrik ini dioperasikan on-grid ke jaringan distribusi, yang dikenal dengan istilah pembangkit terdistribusi (DG). Kehadiran DG dalam jaringan distribusi ini menimbulkan tantangan baru dalam oparasional jaringan distribusi. Dalam penelitian ini, optimisasi jaringan distribusi dilakukan menggunakan metode SKB. Dalam optimisasi, tujuan yang ingin dicapai tidak hanya satu objektif tetapi multi-objektif. Optimisasi multi-objektif bertujuan untuk menurunkan rugi daya, perbaikan profil tegangan, dan keseimbangan beban jaringan. Metode SKB memiliki keunggulan dalam konvergen si yang cepat dan menghindari minimu m lokal. Untuk menguji keunggulan metode SKB, dilakukan optimisasi jaringan distribusi dengan dan tanpa integrasi DG pada jaringan distribusi standar IE EE model 33bus dan 71-bus. Hasil simulasi menunjukkan bahwa metode SKB mampu menghasilkan optimisasi yang lebih baik dibandingkan sebelum optimisasi. Parameter keberhasilan optimisasi adalah rug-rugi daya aktif yang minimal, profil tegangan yang sesuai, dan keseimbangan beban yang tetap terjaga. Optimisasi ini berhasil meningkatkan efisiensi jaringan distribusi rata-rata $0,61 \%$.

Kata kunci- optimisasi multi-objektif, rekonfigurasi jaringan, jaringan distribusi, pembangkit terdistribusi, sistem kekebalan buatan 


\section{PENDAHULUAN}

Dalam satu dekade terakhir, pengembangan pembangkit listrik energi terbarukan skala kecil hingga menengah semakin banyak diterapkan [1]. Pembangkit-pembangkit tersebut diintegrasikan pada sistem jala-jala melalui jaringan distribusi. Pembangkit-pembangkit listrik tersebut dikenal dengan sebitan pembangkit terd istribusi (distributed generation, DG) [2]. Pembangkit terdistribusi (DG) dapat didefinisikan sebagai pembangkit tenaga listrik dalam kapasitas kecil, umumnya kurang dari $10 \mathrm{MW}$, biasanya dihasilkan dari sumber energi terbarukan yang dihubungkan ke transmisi tenaga listrik atau sistem distribusi [3]. Kebutuhan sumber energi terbarukan terkait dengan keterbatasan sumber daya energi fosil dan masalah lingkungan membuat teknologi baru seperti fotovoltaik surya, turb in angin, turbin air, dan sumber energi terbarukan lainnya semakin populer. Pemerintah Indonesia telah menetapkan target pasokan energi listrik yang berasal dari pembangkit yang didistribusikan yang bersumber dari energi terbarukan yang terintegrasi ke dalam jaringan interkoneksi hingga $23 \%$ dari total pembangkit listrik pada tahun 2025 [4].

Integrasi DG dalam sistem tenaga listrik mengakibatkan peningkatan tegangan listrik pada sistem distribusi, terutama di daerah yang dekat dengan sumber DG [5], [6]. Kenaikan tegangan harus dikendalikan agar tidak terjadi kenaikan tegangan yang berlebihan. Cara konvensional yang digunakan untuk mengontrol tegangan ini adalah dengan memanfaatkan operator jaringan distribusi. Seiring dengan pertumbuhan dan kompleksitas sistem, pendistribusian prosedur tersebut tidak lagi mencukupi, sehingga diperlukan perangkat teknologi informasi komunikasi (TIK) untuk merencanakan, merancang, dan mengoperasikan sistem distribusi tenaga listrik [7]. Salah satu manfaat utama menggunakan TIK adalah untuk memfasilitasi pengoperasian rekonfigurasi jaringan untuk meminimalkan kehilangan daya dalam sistem distribusi [8] [10].

Dalam pengoperasiannya, sistem distribusi direncanakan sebagai jaringan tipe radial. Jen is jaringan ini merupakan jaringan yang lemah karena memiliki keandalan yang rendah yang mengandalkan feeder [11]. Jaringan radial terdiri dari satu set pengumpan dengan sumber tenaga listrik. Dalam kondisi ini, feeder juga dapat dihubungkan ke jaringan lain untuk kasus kontingensi dan interoperabilitas. Di sisi lain, tujuan umum dari utilitas listrik adalah untuk mengurangi kerugian sistem. Beberapa cara telah dilakukan untuk mencapai tujuan tersebut, antara lain memasang kapasitor, menaikkan level tegangan, memasang regulator tegangan, atau melakukan rekonfigurasi jaringan. Di antara metode ini, rekonfigurasi jaringan adalah metode yang paling efekt if dan murah [12].

Masalah rekonfigurasi jaringan distribusi bersifat ko mpleks, kombinatorial, dan mu lti-objekt if [13]. Dalam hal ini, melibatkan banyak bus pada jaringan distribusi, bahkan lebih sulit jika hanya menerapkan metode klasik. Untuk menyelesaikan secara optimal, rekonfigurasi jaringan harus mempertimbangkan aspek-aspek penting dari jaringan distribusi [14]. Aspek-aspek tersebut adalah pemodelan jaringan distribusi yang tepat, metode yang cepat dan tepat untuk menangani perubahan konfigurasi, menghitung aliran daya, jumlah dan komposisi fungsi objekt if dan kekangan, serta teknik pengambilan keputusan yang digunakan untuk menentukan konfigurasi jaringan yang ideal [15].

Banyak peneliti telah mengusulkan pendekatan yang berbeda untuk masalah rekonfigurasi jaringan distribusi. Pendekatan tersebut meliputi penggunaan metode genetika (GA) [16], fuzzy set [17], simulated annealing [18], pendekatan hybrid fuzzy-ant colony [19], particle swarm optimization (PSO) [20], dan metode optimisasi lainnya. Rekonfigurasi jaringan distribusi merupakan masalah multiobjektif.

Kerangka multi-objektif memperhitungkan keseimbangan antara tujuan yang saling bertentangan, seperti kehilangan daya dan keandalan jaringan. Tujuan lain yang telah dipertimbangkan adalah profil tegangan, load balancing, jumlah operasi switching, dan indeks kontinuitas [20].

Makalah ini bertujuan untuk mengelola jaringan distribusi, terutama dengan adanya pembangkit terdistribusi dinamis. Manajemen jaringan distribusi dinamis melalui pendekatan multi-objekt if saat merekonfigurasi jaringan distribusi. Metode yang digunakan adalah sistem kekebalan buatan (SKB) tipe seleksi klonal, dimana bagian depan pareto tidak dominan dan dilengkapi dengan teori grafik [21], [22]. Metode pengoptimalan SKB men iru sistem kekebalan manusia dengan pola pengenalan, me mori, dan fitur pembelajaran adaptif [23]. Berdasarkan studi literatur, metode SKB lebih kokoh dan stabil dibandingkan dengan metode GA dan PSO, karena proses mencari solusi di seluruh ruang pencarian, menghindari konvergensi prematur ke minimum lokal [24], [25]. Metode SKB tipe seleksi klonal (clonal selection) digunakan pada makalah ini. Teknik ini berguna untuk menghasilkan pohon merentang minimum selama proses evolusi. Pendekatan ini dapat meningkatkan kinerja komputasi metode SKB.

Penulisan dalam makalah ini diawali dengan bagian Pendahuluan yang berisi latar belakang, permasalahan, tinjauan pustaka, dan tujuan penelitian. Bagian selanjutnya adalah Metode, di mana pada bagian ini menjelaskan metode SKB yang digunakan dalam optimisasi jaringan distribusi dan langkah-langkah penelitian yang dilakukan. Bagian setelah Metode adalah Hasil dan Pembahasan yang berisi hasil optimisasi jaringan distribusi model 33 bus dan 71 bus yang disertai dengan analisis dari setiap hasilnya. Selanjutnya adalah bagian Penutup yang berisi kesimpulan dari penelitian yang telah dilakukan.

\section{METODE}

\section{A. Integrasi DG pada Jaringan Distribusi}

Kehadiran pembangkit listrik energi terbarukan dipicu oleh beberapa faktor, antara lain perkembangan teknologi pembangkit energi terbarukan yang semakin baik dari tahun ke tahun dan isu lingkungan yang semakin marak. Ada beberapa keuntungan dalam penyelenggaraan pembangkit energi terbarukan yaitu pembangkit ini dapat dibangun oleh perseorangan atau kelompok masyarakat, pembangkit dengan bahan bakar yang tidak akan habis, dan pembangkit ini sangat ramah lingkungan. Pembangkit listrik ini umumnya terdiri 
dari pembangkit energi terbarukan, yang disebut pembangkit terdistribusi (DG) [26].

Integrasi DG dapat men imbulkan beberapa masalah seperti penambahan daya reaktif pada jaringan, masalah proteksi, pengkondisian daya, kualitas daya, dan tarif listrik. Beberapa teknologi DG, misalnya turbin angin, menggunakan generator asinkron yang mengkonsumsi daya reaktif dari jaringan. Hal ini menyebabkan defisit daya reakt if baik secara lokal maupun global, dan akibatnya, menyebabkan profil tegangan yang buruk yang menyebabkan tegangan runtuh. Apalagi DG mengakibatkan sistem proteksi dalam jaringan distribusi yang lebih ru mit dari segi selektivitas dan koordinasi. Alasan aliran daya di jaringan distribusi dengan unit DG tidak lagi searah dan perubahan tingkat kesalahan. Selain itu, beberapa teknologi DG, seperti fotovoltaik surya dan fuel cell, tidak memiliki putaran balik untuk merespons perubahan cepat dalam keseimbangan daya lis trik.

Berdasarkan teknologi dan karakteristik sumber tenaga listrik terdapat empat jenis DG yaitu:

- Tipe I: DG menyuntikkan daya aktif (P) saja, misalnya fotovoltaik.

- Tipe II: DG hanya menginjeksikan daya reaktif (Q), misalnya kompensator sinkron.

- Tipe III: DG menyuntikkan daya aktif tetapi menyerap daya reaktif, misalnya, generator asinkron. Daya reaktif yang diserap oleh generator asinkron diberikan oleh $\mathrm{QER}=\left(0,5+0,04 \mathrm{P}^{2}\right)$.

- Tipe IV: DG menyuntikkan daya aktif dan reaktif, mis alnya generator sinkron.

Dalam makalah ini, dua jen is DG diasumsikan beroperasi di jaringan distribusi radial, yaitu fotovoltaik surya dan pembangkit listrik tenaga angin. DG fotovoltaik surya menyuntikkan daya aktif sedangkan DG pembangkit tenaga angin yang menggunakan generator asinkron menyuntikkan daya aktif dan daya reaktif.

Integrasi DG pada jaringan distribusi tenaga listrik dapat meningkatkan performa jaringan secara umum [27]. Pada lokasi-lokasi yang diinjeksikan DG, profil tegangan menjadi semakin baik dan rugi-rugi daya listrik menjadi menurun. Hal ini disebabkan dengan diinjeksikannya DG pada jaringan, DG sebagai pembangkit listrik dimana harus memiliki tegangan dan frekuensi yang sama dengan tegangan nominal dan frekuensi jaringan distribusi, seolah-olah memberikan penyegaran pada jaringan di lokasi injeksi DG. Namun demikian, pada kondisi ini pola sebaran rugi-rugi daya pada jaringan distribusi pada konfigurasi ini menjadi berubah dibandingkan dengan sebelum integrasi DG. Rugi-rugi daya pada jaringan distribusi akan lebih dioptimalkan dengan melakukan rekonfigurasi jaringan.

\section{B. Sistem Kekebalan Buatan (SKB)}

Prinsip-prinsip SKB digunakan untuk menjelaskan respons utama sistem kekebalan dengan menjadi adaptif terhadap stimulasi antigen, seperti yang dije laskan pada Gambar 1 [28]. Sistem kekebalan tubuh merupakan sistem yang kompleks, karena berhubungan dengan sel-sel dan molekul dalam tubuh manusia. Sistem kekebalan adalah organisme yang merepresentasikan mekanisme identifikasi yang mampu menyediakan dan memerangi disfungsi sel manusia itu sendiri dan tindakan mikroorganisme infeksius eksogen. Tindakan mikroorganis me ini mengenali variasi sel dan zat asing yang hampir tidak terbatas, me mbedakannya dari sel non-infeksius primer. Saat terkena antigen, limfosit B merespons dengan memproduksi antibodi di dalam tubuh. Setiap sel mengeluarkan satu jenis antibodi yang khusus untuk antigen. Antibodi ini terikat, yang bertindak sebagai reseptor sel, dan dengan sinyal kedua dari sel aksesori, seperti sel T-helper, antigen merangsang sel B untuk berkembang biak dengan membelah.

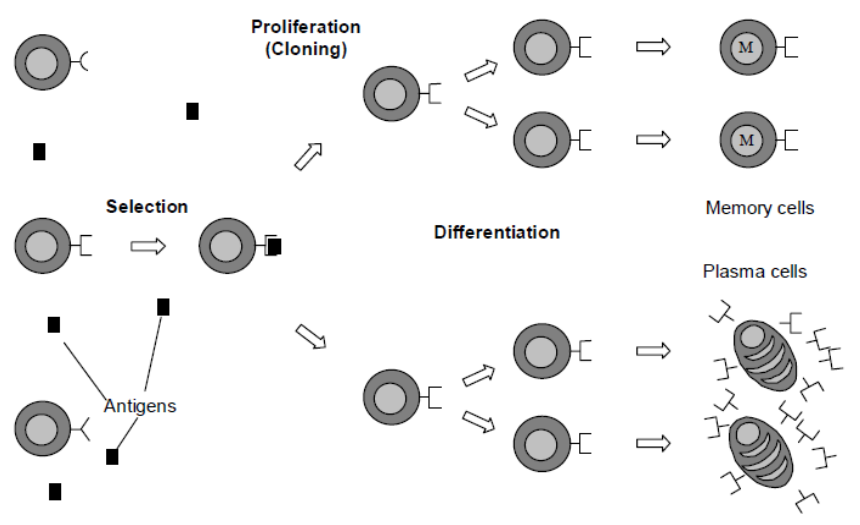

Gambar 1. Mekanisme sistem kekebalan tubuh

Selanjutnya, sel B matang dan menjadi sekresi antibodi terminal sel non-individu, yang disebut sel plasma. Mekanisme proliferasi sel dengan membelah menghasilkan klon, yaitu sel atau kumpulan sel yang merupakan keturunan dari satu sel. Selanjutnya, limfosit berkembang biak menjadi sel plasma yang berdiferensiasi menjadi sel B memori yang berumur panjang. Sistem kekebalan kompleks ini diadopsi sebagai sistem komputasi untuk pengoptimalan multi-tujuan. Metode SKB ini memiliki banyak fitur menarik untuk memecahkan masalah optimasi multi-tujuan. Metode SKB ini telah diterapkan pada bidang kendali yang kokoh, kendali adaptif, robotika, pengoptimalan, sistem berbasis gradien, sistem multi-agen untuk solusi pendekatan jaringan saraf, klasifikasi citra, data mining, pengiriman optimal, dan pengisian ulang kendaraan listrik dalam sistem distribusi. Metode SKB digunakan karena memiliki keunggulan keunikan, deteksi anomali, pengenalan benda asing, penguatan pembelajaran dan memori, dan pengenalan pola. Fitur-fitur ini memungkinkan SKB menemukan solusi yang baik untuk berbagai masalah dan menghindari jebakan minimum lokal dalam komputasi. Metode SKB juga mampu menyelesaikan masalah yang belum pernah dihadapi sebelumnya.

Afinitas antara antibodi dan antigen dapat ditentukan menggunakan teknik yang berbeda seperti aturan pencocokan dan ukuran jarak [29]. Salah satu teknik yang umum digunakan adalah jarak Euclidean, yang cocok jika menggunakan representasi vektor bernilai nyata. Untuk menjelaskan cara kerja ClonalG menggunakan jarak Euclidean, misalkan $G d=\{G d 1, G d 2, \ldots, G d N\}$ dan $G c=$ $\{G c 1, G c 2, \ldots, G c N\}$ masing-masing menunjukkan himpunan 
antigen dan antibodi, $N$ adalah pendukung dari pesanan. Kemudian, derajat kecocokan $d$ antara $G d$ dan $G c$ dapat dihitung berdasarkan jarak Euclidean:

$$
d=\sum_{i=1}^{N}\left(G d_{i}-G c_{i}\right)^{2}
$$

Selanjutnya $d$ dibandingkan dengan threshold $\lambda$, dan diperoleh error matching $E$ dengan menggunakan persamaan:

$$
E=d-\lambda
$$

Jika $E>0$, maka dianggap kedua vektor tersebut tidak cocok, sehingga antigen tersebut tidak dikenali oleh antibodi. Jika $E \leq 0$, disimpulkan $G d$ dan $G c$ cocok, maka antigen dikenali oleh antibodi. Rentang umum untuk penghitungan afinitas bervariasi antara 0 dan 1 .

Untuk pematangan afinitas, metode ClonalG mengasumsikan bahwa $n$ antibodi afinitas tertinggi terurut naik, dan jumlah klon yang dinaikkan untuk semua $n$ antibodi terpilih diberikan oleh:

$$
N c=\sum_{i=1}^{n} \operatorname{round}\left(\frac{\beta \cdot N}{i}\right)
$$

dengan $N_{C}$ adalah jumlah klon untuk setiap antigen, $\beta$ adalah faktor kloning yang menentukan faktor skala untuk jumlah klon untuk antibodi yang dipilih dan $\beta$ nilai umum adalah $\in$ $(0,1], N$ adalah jumlah total antibodi, dan round() adalah operator yang merotasi argumen ke bilangan bulat terdekat. Setiap bagian dari jumlah ini sesuai dengan ukuran klon dari setiap antibodi yang dipilih, misalnya untuk $N=100$ dan $\beta=1$, antibodi afinitas tertinggi $(i=1)$ a kan menghasilkan 100 klon, sedangkan afinitas antibodi menghasilkan hasil tertinggi kedua dari 50 klon, dan selanjutnya.

C. Metode Sistem Kekebalan Buatan (SKB) untuk Optimisasi Jaringan Distribusi

Metode SKB untuk optimasi multi-tujuan dalam rangka rekonfigurasi jaringan distribusi pada makalah ini ditunjukkan pada Gambar 2. Metode SKB diterapkan pada rekonfigurasi jaringan distribusi dengan menggunakan empat jenis fungsi tujuan dalam rangka meningkatkan kinerja sistem distribusi tenaga lis trik, yaitu:

- Fungsi untukmeminimalkan kehilangan daya nyata.

- Fungsi untukmeminimalkan deviasi tegangan bus.

- Fungsi untukmeminimalkan indeks arus cabang.

- Fungsi untuk menyeimbangkan beban feeder.

Metode SKB merupakan pendekatan kecerdasan komputasi yang diinspirasi oleh sistem kekebalan vertebrata dan telah menjadi metode yang populer dalam menyelesaikan masalah optimasi dalam jaringan distribusi [30]. Pada metode SKB, salah satu variabel penting yang digunakan adalah populasi $(X)$, dan mutasi populasi tersebut diimplementasikan dalam persamaan berikut:

$$
X_{i+m j}=X_{y}+N\left(0, \beta\left(X_{j \max }-X_{j m i n}\right)\left(f_{1} / f_{\max }\right)\right.
$$

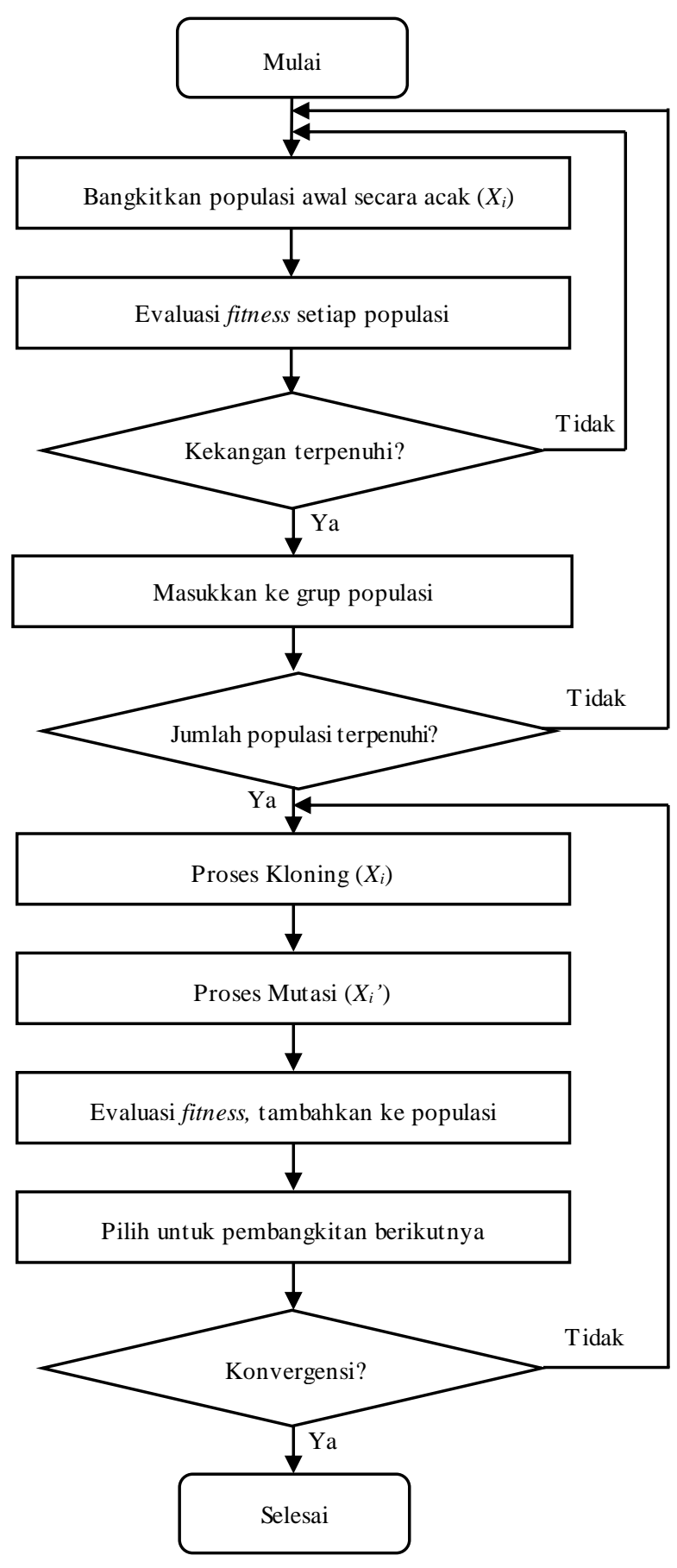

Gambar 2. Diagram alir metode SKB

Tahapan penyelesaian masalah optimasi menggunakan metode SKB seperti terlihat pada Gambar 2 dijelaskan sesuai langkah-langkah berikut:

1) Bangkitkan populasiawal secara acak $\left(X_{i}\right)$

Untuk meminimalkan kehilangan daya, maka kombinasi tie switch dari jaringan distribusi ke kondisi sebelum rekonfigurasi harus ditentukan terlebih dahulu. Penentuan ko mbinasi tie switch dilakukan secara acak. Jumlah tie switch ditentukan berdasarkan jumlah tie switch yang terdapat dalam jaringan distribusi. 


\section{2) Evaluasi fitness setiap populasi}

Untuk meminimalkan kehilangan daya, kesesuaian SKB dianggap sebagai kerugian total dalam sistem distribusi. Total kerugian dievaluasi dengan menyelesaikan program aliran daya. Ini dilakukan dengan me manggil program aliran daya ke dalam SKB sebagai program utama. Optimasi juga memperhatikan kendala tegangan pada sistem distribusi agar tegangan minimum dan maksimum tidak terlampaui.

\section{3) Proses kloning}

Dalam proses ini, kloning dilakukan ko mbinasi tie switch dan total rugi daya di jaringan distribusi.

\section{4) Proses mutasi}

Dalam proses ini, nilai kloning dimutasi dengan menerapkan pembawa mutasi. Mutasi hanya pada variasi operator digunakan untuk menghasilkan keturunan dari setiap orang tua. Kebugaran keturunan dihitung dengan memanggil program aliran daya.

\section{5) Proses seleksi}

Proses seleksi dilakukan dengan menerapkan strategi seleksi berdas arkan prioritas.

\section{6) Uji konvergensi}

Prosedur pengujian dilakukan untuk menentukan penghentian optimasi kriteria konvergensi. Kriteria konvergensi ditentukan oleh selisih antara fitness maksimum dan minimum kurang dari 0,0001. Jika kondisi konvergensi tidak terpenuhi, maka proses diulang hingga tercapai kondisi konvergensi.

$$
\text { maximum }_{\text {fitness }}-\text { minimum }_{\text {fitness }} \leq 0,0001
$$

Diagram alir metode SKB untuk optimalisasi konfigurasi jaringan distribusi ditunjukkan pada Gambar 2. Metode SKB untuk optimisasi multi-objektif dalam rangka rekonfigurasi yang optimal dalam makalah ini diimplementasikan dalam perangkat lunak Matlab.

\section{Formulasi Optimisasi Multi-objektif Jaringan Distribusi}

Tujuan utama dari rekonfigurasi jaringan adalah untuk meminimalkan kehilangan daya aktif dan meningkatkan kualitas tegangan [31]. Kendala dari masalah optimasi konfigurasi adalah persamaan aliran beban, batas atas dan bawah tegangan bus, serta batas atas dan bawah arus saluran [32]. Optimasi konfigurasi untuk minimisasi kehilangan daya aktif dapat diformulasikan sebagaiberikut [33]:

$$
\min P_{\text {loss }}=\sum_{i=1}^{N_{k}} R_{i} \frac{\left(P_{i}^{2}+Q_{i}^{2}\right)}{V_{i}^{2}}
$$

Mengacu kepada:

$$
\begin{gathered}
F(X)=0 \\
V_{i, \text { min }} \leq V_{i} \leq V_{i, \text { max }} \\
I_{i, \text { min }} \leq I_{i} \leq I_{i, \text { max }}
\end{gathered}
$$

dimana $P_{\text {loss }}$ adalah fungsi biaya dari kehilangan daya aktif; $N_{k}$ adalah jumlah cabang; $R_{i}$ adalah hambatan pada bus ke- $i ; P_{i}$ dan $Q_{i}$ masing-masing adalah daya aktif dan reaktif yang mengalir keluar dari bus; $V_{i}$ adalah besaran tegangan pada bus ke- $i ; V_{i, \min }$ dan $V_{i, \max }$ masing-masing adalah batas tegangan bawah dan atas pada bus ke- $i ; I_{i}$ adalah besaran arus pada $b u s$ ke- $i ; I_{i, \text { min }}$ dan $I_{i, \text { max }}$ masing-masing adalah batas arus bawah dan atas pada bus ke-i.

\section{HASIL DAN PEMBAHASAN}

Pada makalah ini dilakukan pengujian dua sistem distribusi kelistrikan yaitu sistem uji jaringan distribusi radial IEEE 33-bus dan sistem distribusi radial IEEE 71-bus. Kedua sistem uji jaringan distribusi diasumsikan telah terintegrasi dengan DG. Rekonfigurasi jaringan distribusi dengan integrasi DG menggunakan metode SKB telah diimplementasikan pada perangkat lunak Matlab. Berdasarkan teknologi DG, dimodelkan dua jenis DG yang terhubung ke jaringan distribusi pada makalah ini, yaitu fotovoltaik surya dan pembangkit listrik tenaga angin. Pengoperasian DG diasumsikan dalam kondisi steady state. Oleh karena itu, DG fotovoltaik surya menyuntikkan daya aktif sedangkan DG pembangkit tenaga angin menyuntikkan daya aktif dan daya reaktif.

\section{A. Uji Sistem Jaringan Distribusi IEEE 33-bus}

Pada bagian ini, dijelaskan optimasi konfigurasi jaringan distribusi model IEEE 33-bus dengan menggunakan metode SKB. Optimasi konfigurasi diimplementasikan pada jaringan distribusi radial 33-bus, 12,66 kV dalam dua kondisi, yaitu tanpa integrasi DG dan dengan integrasi DG. Sistem distribusi radial terdiri dari satu penyulang utama dan tiga penyulang lateral. Sistem in i memiliki 33 bus dan 32 seksi, seperti yang ditunjukkan pada Gambar 3.

Jaringan distribusi me miliki 32 sectionalizing switches dan 5 tie switch. Sectionalizing switches adalah sakelar yang berada pada posisi tertutup pada kondisi normal, sedangkan tie switch merupakan sakelar yang berada pada posisi terbuka pada kondisi normal. Data beban dan jaringan distribusi radial IEEE 33-bus dapat dilihat pada referensi [20]. Total beban sistem adalah $3715 \mathrm{~kW}$ dan basis sistem adalah $\mathrm{V}=12,66 \mathrm{kV}$ dan $\mathrm{S}=10$ MVA. Parameter SKB yang telah digunakan pada sistem distribusi 33 bus terd iri dari ukuran populasi 20 dan iterasi maksimum 1000. Tegangan minimum dan maksimum ditetapkan masing-masing sebesar 0,90 dan 1,00 p.u. Pada konfigurasi awal, sistem distribusi model IEEE 33-bus telah diset pada lima buah saklar ikat, yaitu saklar masing-masing 33, 34, 35, 36, dan 37, seperti dapat dilihat pada Gambar 3.

Untuk menganalisis dampak integrasi DG terhadap jaringan distribusi, maka telah dipasang tiga DG pada bus 18 , 22, dan 33, dengan kapasitas masing-masing $2 \mathrm{MW}, 1,98 \mathrm{MW}$, dan 1,70 MW seperti pada Tabel I, dengan lokasi dan kapasitas ketiga DG tersebut paling optimal seperti yang disebutkan dalam referensi [20]. Model DG yang telah digunakan dalam makalah ini terd iri dari fotovoltaik surya dan pembangkit listrik tenaga angin. 


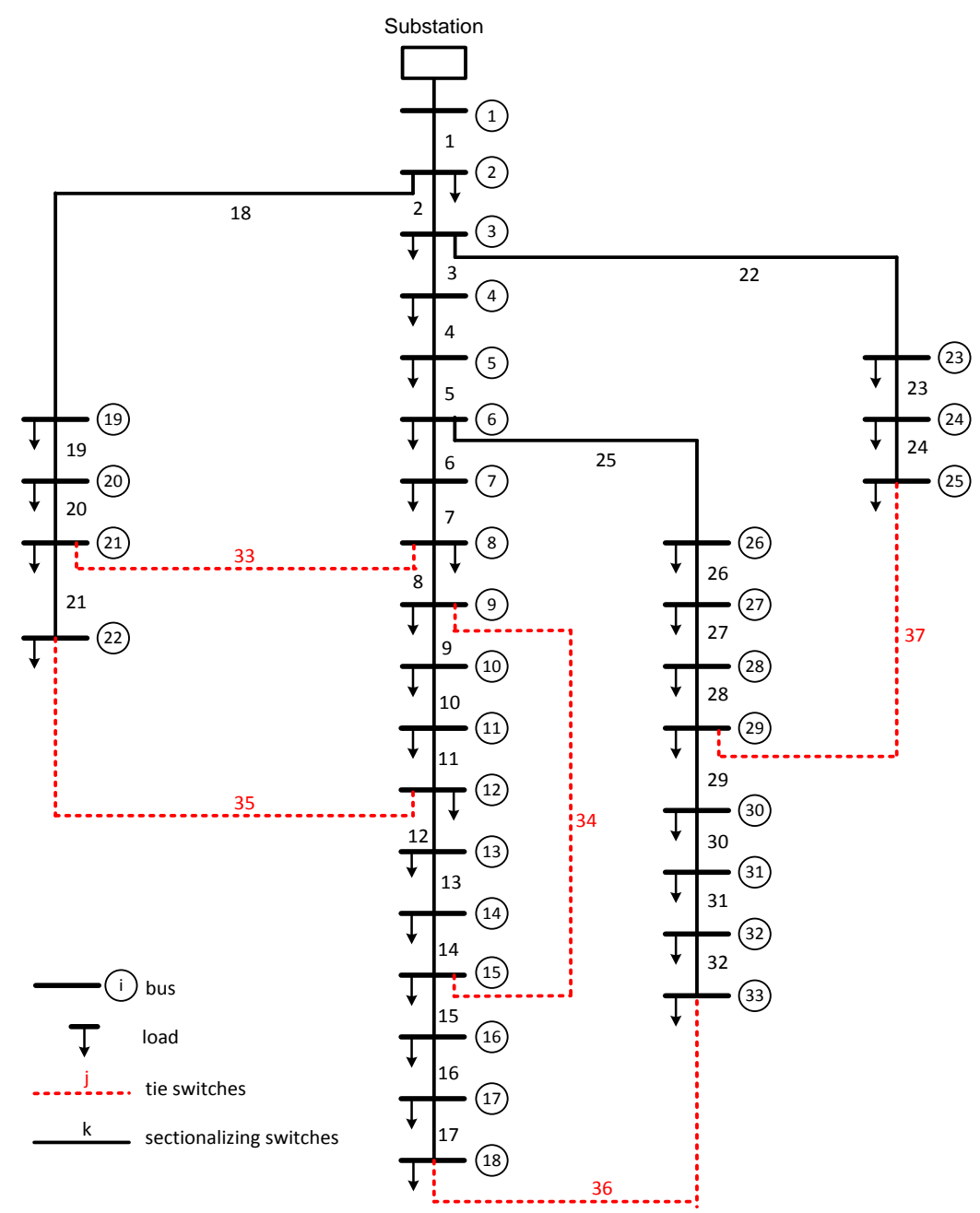

Gambar 3. Konfigurasi awal jaringan distribusi radial IEEE 33-bus

TABEL I. LOKASI DAN KAPASITAS DG PADA SISTEM UII IEEE 33-BUS

\begin{tabular}{|c|c|c|c|c|}
\hline Nama & $\begin{array}{c}\text { Nomor } \\
\text { Bus }\end{array}$ & $\begin{array}{c}\text { Daya Akif } \\
\text { (MW) }\end{array}$ & $\begin{array}{c}\text { Faktor } \\
\text { Daya }\end{array}$ & $\begin{array}{c}\text { Daya Reaktif } \\
\text { (MVAr) }\end{array}$ \\
\hline DG-1 & 18 & 2,00 & 1,00 & 0 \\
\hline DG-2 & 22 & 1,98 & 0,90 & 1,11 \\
\hline DG-3 & 33 & 1,70 & 0,85 & 1,05 \\
\hline \multicolumn{2}{|c|}{ Total } & 5,68 & - & 2,16 \\
\hline
\end{tabular}

Dalam makalah ini diasumsikan bahwa faktor daya dari semua DG fotovoltaik surya adalah satu, sedangkan pembangkit listrik tenaga angin adalah tertinggal 0,9 dan 0,85. Integrasi ketiga DG pada jaringan distribusi radial IEEE 33bus ditunjukkan pada Gambar 4. Jaringan distribusi radial IEEE 33-bus yang telah terpasang tiga DG tersebut selanjutnya direkonfigurasi menggunakan metode SKB untuk mendapatkan konfigurasi jaringan yang paling optimal. Hasil optimasi ditunjukkan pada Gambar 5, Gambar 6, Gambar 7, Gambar 8, dan Tabel II.

Gambar 5 menunjukkan fase perubahan kehilangan daya menjadi perubahan iterasi selama optimalisasi jaringan distribusi radial 33-bus IEEE dengan integrasi tiga DG.
Variasi jumlah iterasi diterapkan untuk melihat performansi metode SKB dalam optimasi konfigurasi jaringan distribusi.

Dengan menggunakan variasi jumlah iterasi, diharapkan diperoleh informasi bahwa jumlah iterasi terendah untuk mendapatkan konfigurasi terbaik dan waktu komputasi terendah. Hasil optimasi menunjukkan bahwa terdapat 9 fase rugi daya akibat perubahan bilangan iterasi yaitu masingmasing 5, 10, 30, 50, 100, 200, 300, 400, dan 500, seperti yang diilustrasikan pada Gambar 5. Diperoleh konfigurasi optimal pada angka iterasi 500, yaitu perubahan fase kesembilan, dengan waktu komputasi 396,96 detik. Dalam konfigurasi ini, posisi tie switch masing-masing adalah 8, 19, 27, 34, dan 36. Pada iterasi berikutnya, telah dihasilkan konfigurasi yang sama. Pada makalah ini telah dilakukan uji optimasi iterasi hingga 1000 iterasi dan hasil optimal masih pada posisi tie switch yang sama. Konfigurasi optimal ini menghasilkan rugi daya sebesar $27,25 \mathrm{~kW}$ atau dengan kata lain penurunan rugi daya sebesar $85,14 \%$ dibandingkan dengan kehilangan daya sebes ar 202,71 kW pada konfigurasi semula. Konfigurasi optimal dari model jaringan distribusi IEEE 33-bus ditunjukkan pada Gambar 6. Terlihat bahwa konfigurasi hasil optimasi jaringan distribusi menggunakan metode SKB tetap berada pada topologiradial. 


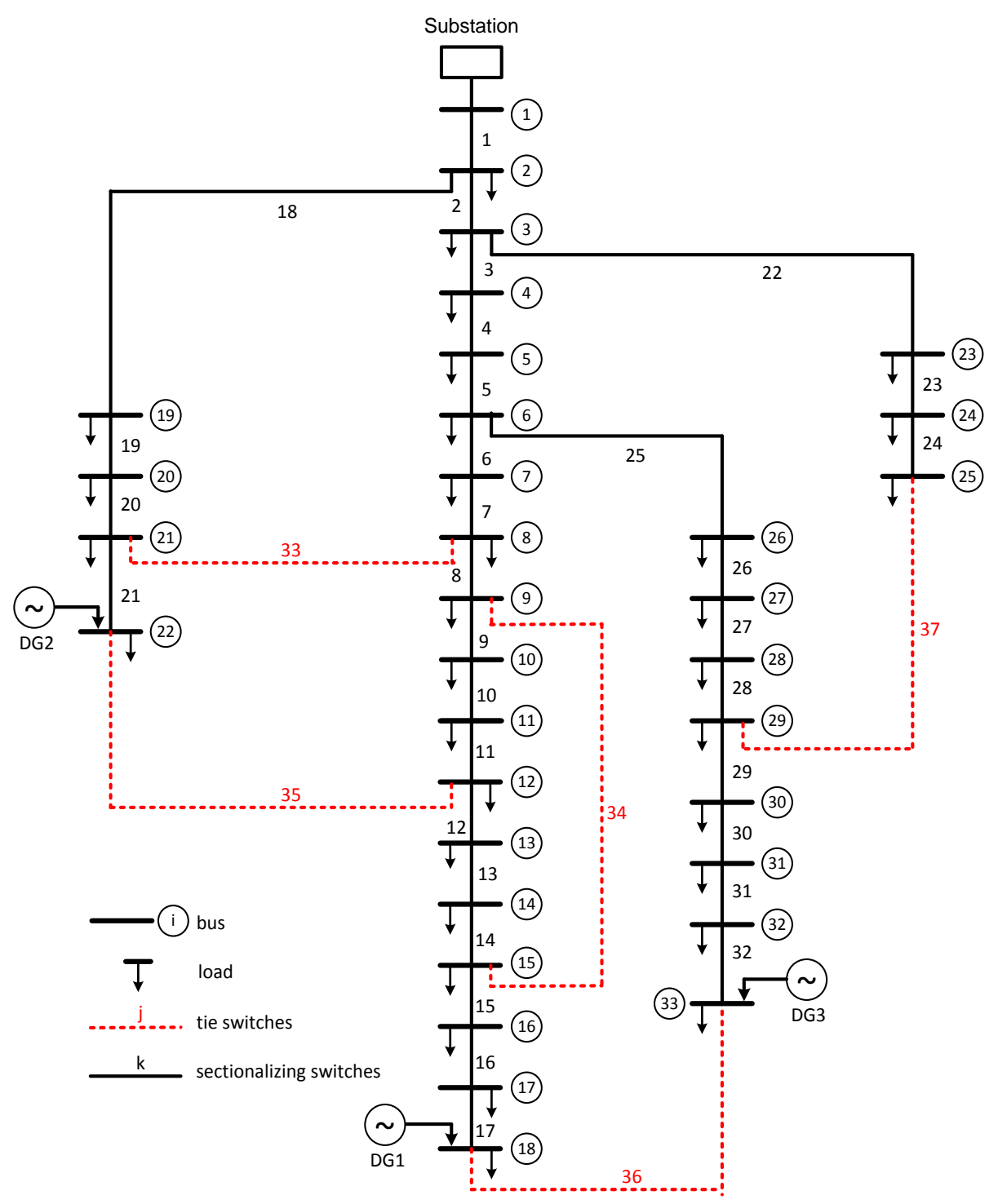

Gambar 4. Integrasi tiga DG pada uji sistem jaringan distribusi radial IEEE 33-bus

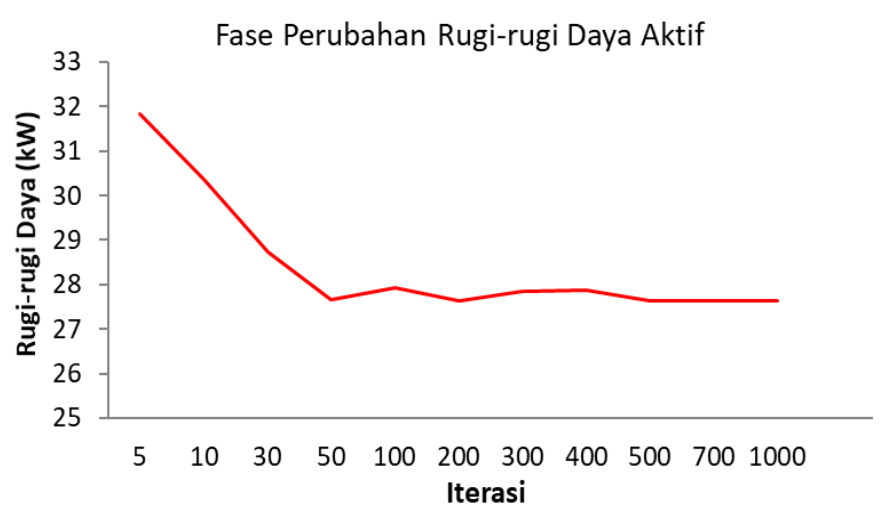

Gambar 5. Fase perubahan rugi-rugi daya aktif pada rentang iterasi saat proses optimisasi jaringan distribusi IEEE 33-bus dengan integrasi tiga buah DG
Gambar 7 menunjukkan grafik dispersi rugi-rugi daya sistem uji distribusi IEEE 33-bus pada kondisi pra rekonfigurasi tanpa DG, pasca rekonfigurasi tanpa DG, pra rekonfigurasi dengan DG, dan pasca rekonfigurasi dengan DG. Dapat dilihat pada Gambar 7 bahwa besarnya rugi daya akt if pada masing-masing cabang dikurangi dengan rekonfigurasi. Misalnya pada cabang 2 pada kondisi pra rekonfigurasi tanpa DG mengalami rugi daya aktif $50 \mathrm{~kW}$, namun setelah rekonfigurasi turun menjadi $24 \mathrm{~kW}$. Penurunan tersebut karena di rekonfigurasi setelah arus yang mengalir pada penghantar 2 lebih kecil dari pada pra rekonfigurasi jaringan. Secara keseluruhan penurunan rugi daya jaringan distribusi tanpa integrasi DG pasca rekonfigurasi adalah 36,21\%, yang menurun dari $202,71 \mathrm{~kW}$ pada kondisi pra rekonfigurasi menjadi $129,65 \mathrm{~kW}$ pada kondisi pasca rekonfigurasi, seperti terlihat pada Tabel II. Rekonfigurasi optimal diperoleh dengan mengubah status tie switch 33, 35, dan 36 menjadi posisi terhubung, sedangkan sectionalizing switch 6, 10, dan 32 dalam keadaan terbuka. 


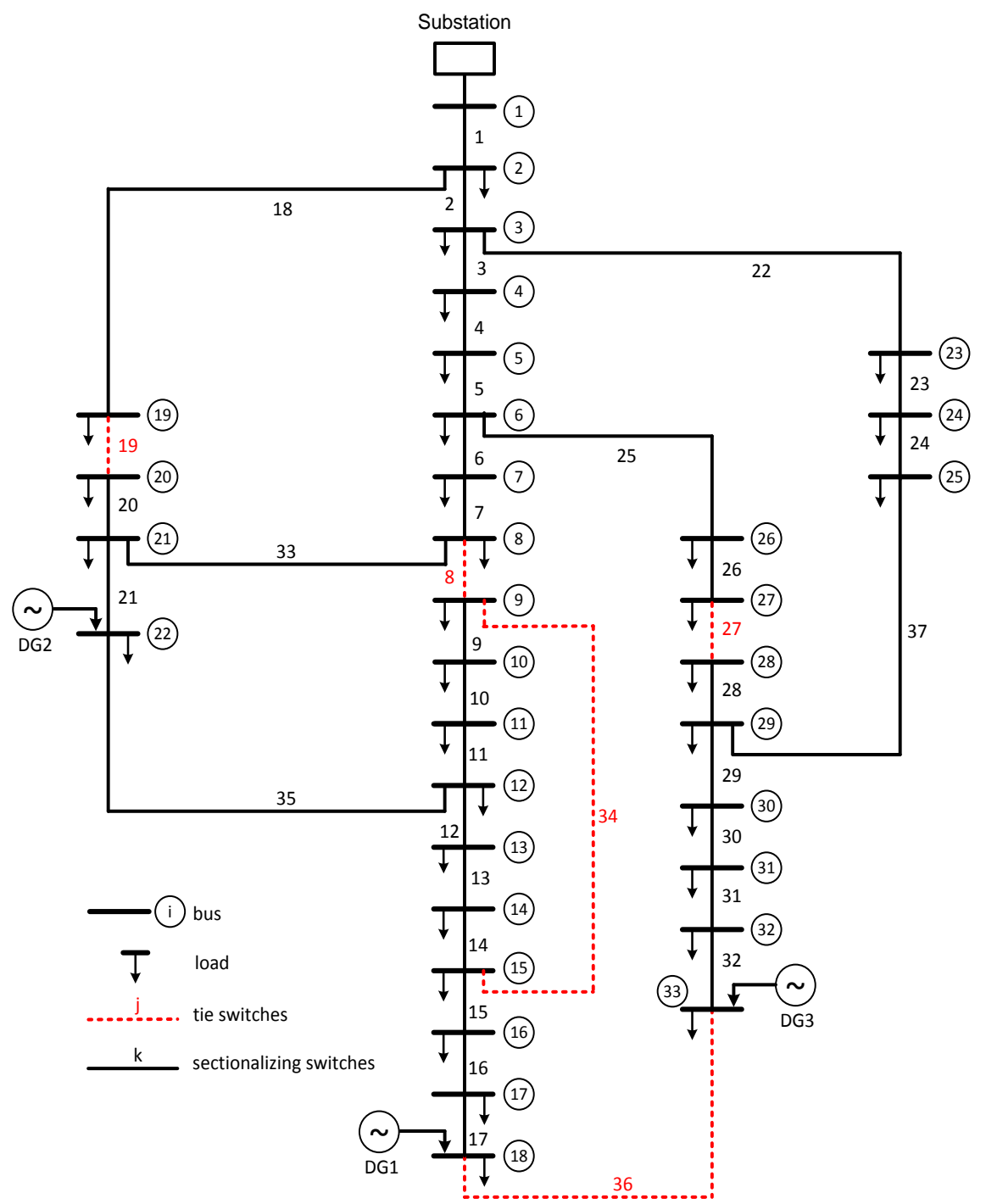

Gambar 6. Konfigurasi optimal pada jaringan distribusi radial IEEE 33-bus dengan integrasi tiga buah DG

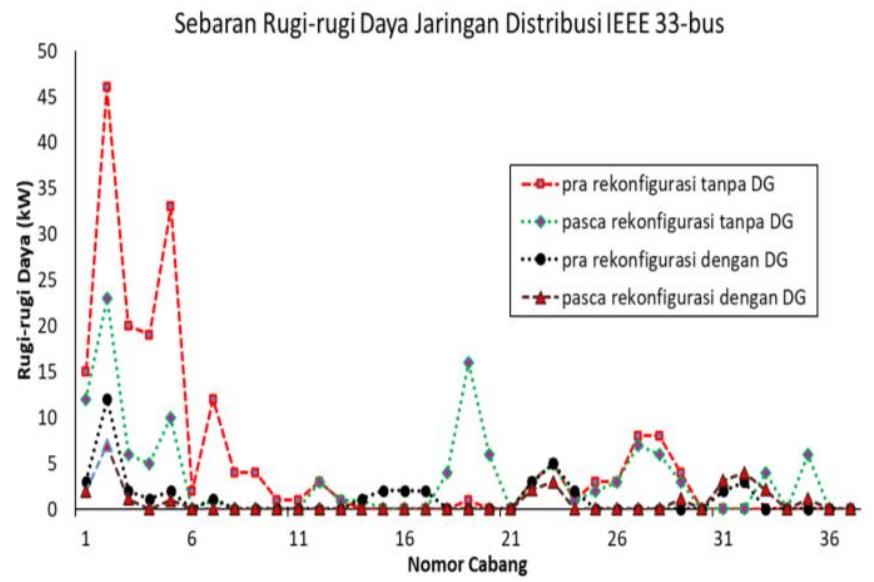

Gambar 7. Sebaran rugi-rugi daya aktif tiap bus pada uji sistem jaringan distribusi IEEE 33-bus

Integrasi DG pada bus 18, 22, dan 33 dengan kapasitas masing-masing $2 \mathrm{MW}, 1,98 \mathrm{MW}$, dan 1,70 MW berpengaruh signifikan terhadap pengurangan rugi daya aktif 33 jaringan distribusi bus, seperti terlihat pada Gambar 7 dan Tabel II. Sebagai contoh, cabang 2 pada kondisi pra dan pasca rekonfigurasi jaringan tanpa DG memiliki rugi daya aktif masing-masing sebesar $50 \mathrm{~kW}$ dan $24 \mathrm{~kW}$, tetapi setelah integrasi DG turun menjadi $12,5 \mathrm{~kW}$. Penurunan tersebut disebabkan adanya integrasi DG pada bus 18, 22, dan 33 yang menyu mbang daya aktif dan reaktif dalam ju mlah yang cukup besar sehingga berpengaruh dalam meningkatkan besaran tegangan bus secara keseluruhan, sehingga arus yang mengalir pada penghantar distribusi jaringan dikurangi. Total rugi daya jaringan distribusi menurun dari $202,71 \mathrm{~kW}$ menjadi 42,21 kW. Selanjutnya konfigurasi jaringan yang optimal semakin mengurangi kehilangan daya menjadi $26,25 \mathrm{~kW}$. Konfigurasi optimal diperoleh dengan membuat status tie switch 33, 35, dan 37 menjadi tertutup, sedangkan status sectionalizing switch 8, 19, dan 27 menjadi terbuka.

Perbandingan profil tegangan jaringan distribusi model IEEE 33-bus pada kondisi pra rekonfigurasi tanpa DG, pasca rekonfigurasi tanpa DG, pra rekonfigurasi dengan DG, dan pasca rekonfigurasi dengan DG, ditunjukkan pada Gambar 8. 
Pengujian optimasi konfigurasi jaringan tanpa DG telah menghasilkan perbaikan profil tegangan pada hampir semua bus, kecuali pada bus 1, 20, 21, dan 22. Pada bus pertama besaran tegangan tetap berada pada nilai ideal yaitu 1 p.u. sesuai dengan nilai maksimum menahan diri dalam pengoptimalan ini. Pada bus 20, 21, dan 22, terjadi sedikit penurunan besaran tegangan sebagai konsekuensi dari perubahan status sakelar. Seperti yang ditunjukkan pada hasil rekonfigurasi pada Gambar 8, terlihat bahwa bus 20, 21, dan 22 terhubung ke lebih banyak bus, sehingga mengakibatkan sedikit penurunan tegangan.

Secara keseluruhan, profil tegangan pasca rekonfigurasi lebih baik daripada konfigurasi awal. Besaran tegangan terendah pra rekonfigurasi adalah 0,911 p.u. pada bus 18 , sedangkan besaran tegangan terendah pasca rekonfigurasi adalah 0,946 p.u. di bus yang sama, seperti yang ditunjukkan pada Gambar 8 dan Tabel II.

Integrasi tiga DG pada model jaringan distribusi IEEE 33bus memiliki pengaruh yang signifikan terhadap peningkatan profil tegangan bus dibandingkan dengan jaringan tanpa integrasi DG pada konfigurasi yang sama. Seperti terlihat pada Gambar 8, besaran tegangan bus keseluruhan meningkat kecuali bus 1 yang telah mencapai 1 p.u. Secara keseluruhan profil tegangan yang meningkat secara signifikan dapat dilihat dari peningkatan besarnya tegangan terendah. Pada kondisi tanpa integrasi DG, tegangan terendah 0,911 p.u. pada bus 18 , sedangkan pada kondisi dengan integrasi DG sebesar 0,978 p.u. pada bus 25 untuk konfigurasi jaringan yang sama, seperti terlihat pada Gambar 8 dan Tabel II. Peningkatan ini terjadi akibat integrasi DG pada bus 18, 22, dan 33 yang menyumbang daya aktif dan reaktif cukup besar sehingga berpengaruh meningkatkan besaran tegangan bus secara keseluruhan. Secara khusus dapat diamati pada bus 18. Besarnya tegangan pada bus merupakan tegangan terendah pada jaringan distribusi IEEE 33-bus pada kondisi awal yaitu 0,911 p.u. Integrasi DG1 dengan kapasitas $2 \mathrm{MW}$ pada bus 18 mampu meningkatkan besaran tegangan menjadi 1 p.u. Begitu juga dengan integrasi DG3 dengan kapasitas 1,70 MW pada bus 33 mampu menaikkan besaran tegangan dari 0,928 menjadi 1 p.u.

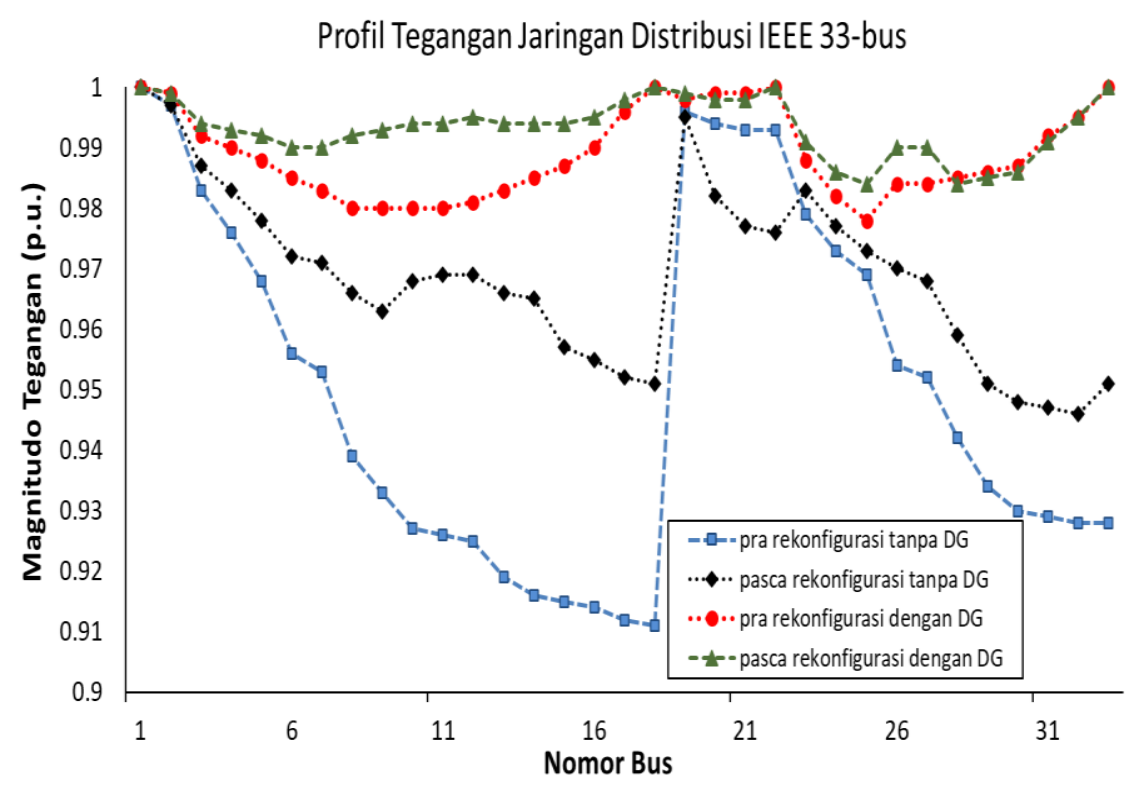

Gambar 8. Profil tegangan uji sistem jaringan distribusi IEEE 33-bus

TABEL II. RESUME HASIL SIMULASI JARINGAN DISTRIBUSI RADIAL IEEE 33-BUS

\begin{tabular}{|c|c|c|c|c|c|c|c|}
\hline \multirow[b]{2}{*}{ Skenario Uji } & \multicolumn{7}{|c|}{ Parameter Analisis } \\
\hline & $\begin{array}{c}\text { Rugi-rugi } \\
\text { Daya Aktif } \\
\text { (kW) } \\
\end{array}$ & $\begin{array}{c}\text { Prosentase Rugi- } \\
\text { rugi Daya Aktif } \\
(\%)\end{array}$ & $\begin{array}{c}\text { Efisiensi } \\
\text { Jaringan } \\
\text { Distribusi (\%) }\end{array}$ & $\begin{array}{c}\text { Tegangan } \\
\text { Minimum } \\
\text { (p.u.) }\end{array}$ & $\begin{array}{l}\text { Tegangan } \\
\text { Maksimum } \\
\text { (p.u.) } \\
\end{array}$ & $\begin{array}{c}\text { Nomor Tie } \\
\text { Switches } \\
\text { Ditutup }\end{array}$ & $\begin{array}{c}\text { Nomor } \\
\text { Sectionalizing } \\
\text { Switches Dibuka }\end{array}$ \\
\hline $\begin{array}{l}\text { Pra rekonfigurasi } \\
\text { tanpa integrasi DG }\end{array}$ & 202,71 & Tidak ada & 94,79 & $\begin{array}{r}0,911 \\
\left(\mathrm{~V}_{18}\right)\end{array}$ & $\begin{array}{l}1,00 \\
\left(\mathrm{~V}_{1}\right)\end{array}$ & Tidak ada & Tidak ada \\
\hline $\begin{array}{l}\text { Pasca rekonfigurasi } \\
\text { tanpa integrasi DG }\end{array}$ & 129,65 & 35,89 & 96,87 & $\begin{array}{r}0,946 \\
\left(\mathrm{~V}_{18}\right)\end{array}$ & $\begin{array}{l}1,00 \\
\left(\mathrm{~V}_{1}\right)\end{array}$ & $\begin{array}{l}33 \\
35 \\
36\end{array}$ & $\begin{array}{c}6 \\
10 \\
32\end{array}$ \\
\hline $\begin{array}{l}\text { Pra rekonfigurasi } \\
\text { dengan integrasi DG }\end{array}$ & 42,21 & 76,27 & 98,93 & $\begin{array}{l}0,978 \\
\left(V_{25}\right)\end{array}$ & $\begin{array}{l}1,00 \\
\left(\mathrm{~V}_{1}\right)\end{array}$ & Tidak ada & Tidak ada \\
\hline $\begin{array}{l}\text { Pasca rekonfigurasi } \\
\text { dengan integrasi DG }\end{array}$ & 26,25 & 85,14 & 99,38 & $\begin{array}{r}0,984 \\
\left(\mathrm{~V}_{25}\right)\end{array}$ & $\begin{array}{l}1,00 \\
\left(\mathrm{~V}_{1}\right)\end{array}$ & $\begin{array}{l}33 \\
35 \\
37\end{array}$ & $\begin{array}{c}8 \\
19 \\
27\end{array}$ \\
\hline
\end{tabular}


Selanjutnya profil tegangan jaringan distribusi ditingkatkan lebih lanjut dengan konfigurasi yang optimal. Hasil simulasi menunjukkan bahwa konfigurasi yang optimal mampu meningkatkan kualitas sistem distribusi tegangan yang dapat dilihat dari besarnya kenaikan tegangan terendah sebesar 0,978 p.u. pada bus 25 menjadi 0,984 p.u. pada bus yang sama. Peningkatan profil tegangan juga terjadi pada hampir semua bus kecuali pada bus yang besarnya tegangan 1 p.u. telah tercapai, seperti yang ditunjukkan pada Gambar 8 . Peningkatan profil tegangan dan pengurangan rugi daya me mberikan kontribusi penting untuk meningkatkan efisiensi jaringan distribusi. Seperti terlihat pada Tabel II bahwa efisiensi jaringan distribusi tanpa DG men ingkat dari 94,79\% menjadi $96,87 \%$ setelah rekonfigurasi optimal. Integrasi ketiga DG pada konfigurasi aslinya mampu meningkatkan efisiensi menjadi 98,93\%. Rekonfigurasi yang optimal pada jaringan distribusi dengan integrasi DG berhasil memaksimalkan efisiensi menjadi 99,38\%.

\section{B. Uji Sistem Jaringan Distribusi IEEE 71-bus}

Pada bagian ini, diu raikan optimasi konfigurasi jaringan distribusi IEEE 71-bus menggunakan metode SKB. Optimisasi konfigurasi diimplementasikan pada jaringan distribusi radial IEEE 71-bus, $11 \mathrm{kV}$ dalam dua kondisi, yaitu tanpa integrasi DG dan dengan integrasi DG. Sistem distribusi radial terdiri dari satu penyulang utama dan tiga penyulang lateral. Sistem ini memiliki 71 bus dan 68 seksi, seperti yang ditunjukkan pada Gambar 9. Jaringan distribusi memiliki 70 sectionalizing switch dan 11 tie switch. Sectionalizing switch adalah sakelar yang berada pada posisi tertutup pada kondisi normal, sedangkan tie switch merupakan sakelar yang berada pada posisi terbuka pada kondisi normal. Beban data dan jaringan distribusi radial IEEE 71-bus dapat dilihat pada [20]. Beban total sistem adalah $4468 \mathrm{~kW}$ dan basis sistem adalah V $=11 \mathrm{kV}$ dan $\mathrm{S}=10 \mathrm{MVA}$. Parameter SKB yang telah digunakan pada sistem distribusi model IEEE 71-bus terdiri dari ukuran populasi 30 dan iterasi maksimum 1000. Tegangan minimum dan maksimum masing-masing ditetapkan pada 0,90 dan 1,00 p.u. Pada konfigurasi awal, sistem distribusi model IEEE 71-bus telah diset pada lima tie switch yaitu masing-masing saklar 69, 70, 71, 72, 73, 74, 75, 76, 77, 78, dan 79, seperti dapat dilihat pada Gambar 9.

Untuk menganalisis dampak integrasi DG terhadap jaringan distribusi, maka diinstal sebanyak empat DG pada bus 16, 29, 35, dan 63, dengan kapasitas masing-masing 0,3 MW, 0,2 MW, 0,1 MW, dan 0,4 MW, seperti yang ditunjukkan pada Tabel III.

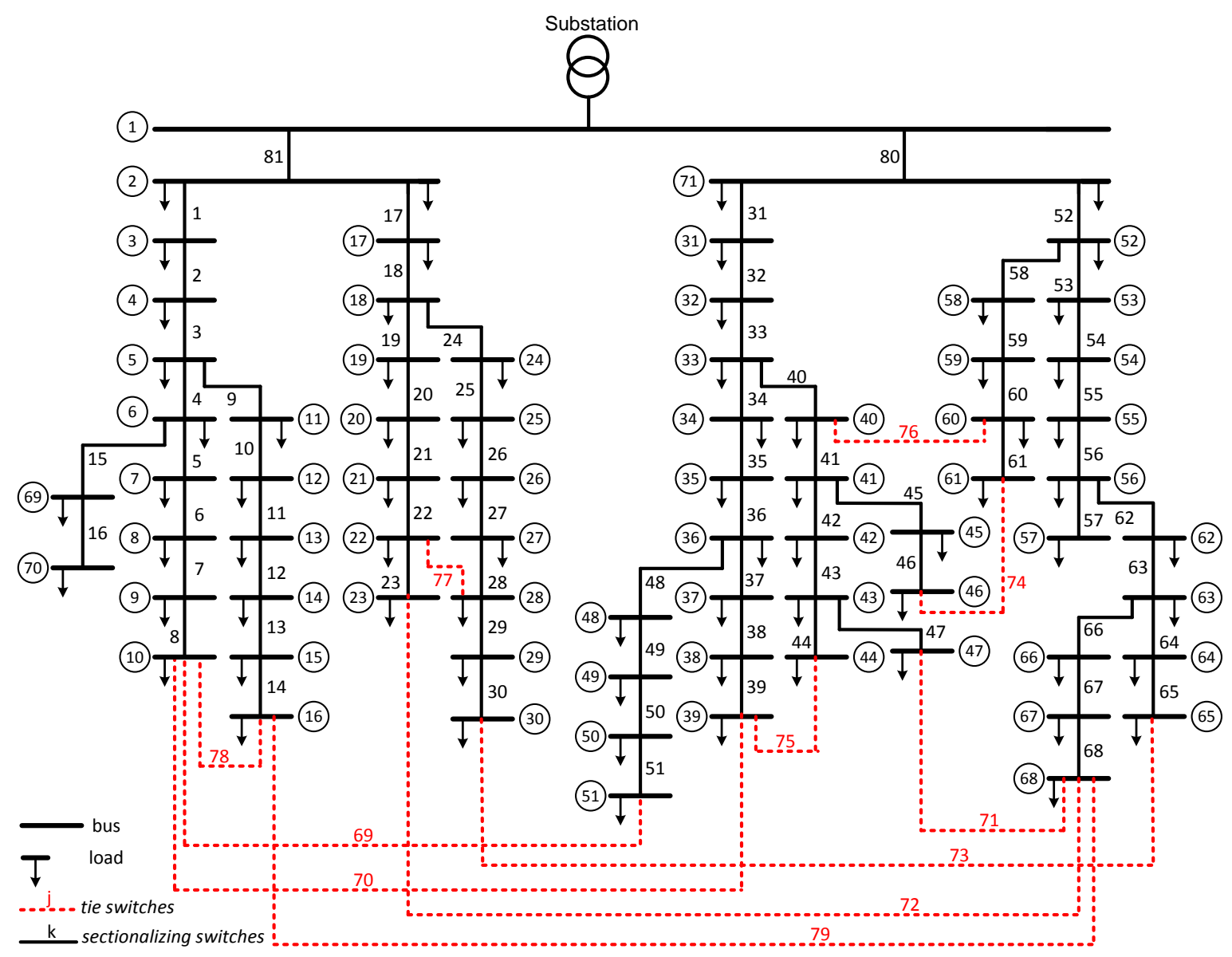

Gambar 9. Konfigurasi awal uji sistem jaringan distribusi IEEE 71-bus 
TABEL III. LOKASI DAN KAPASITAS DGDARI UII SISTEM JARINGAN DISTRIBUSI IEEE 71-BUS

\begin{tabular}{|c|c|c|c|c|}
\hline Nama & $\begin{array}{c}\text { Nomor } \\
\text { Bus }\end{array}$ & $\begin{array}{c}\text { Daya Aktif } \\
\text { (MW) }\end{array}$ & $\begin{array}{c}\text { Faktor } \\
\text { Daya }\end{array}$ & $\begin{array}{c}\text { Daya Reaktif } \\
\text { (MVAr) }\end{array}$ \\
\hline DG-1 & 16 & 0,300 & 0,9 & 0,145 \\
\hline DG-2 & 29 & 0,200 & 1 & 0 \\
\hline DG-3 & 35 & 0,100 & 1 & 0 \\
\hline DG-4 & 63 & 0,400 & 0,9 & 0,194 \\
\hline \multicolumn{2}{|c|}{ Total } & 1,000 & - & 0,339 \\
\hline
\end{tabular}

Lokasi dan kapasitas ketiga DG paling optimal seperti yang dinyatakan dalam [1]. Model DG yang telah digunakan dalam makalah ini terdiri dari fotovoltaik surya dan ladang angin. Asumsi yang digunakan dalam makalah ini yaitu faktor daya dari semua DG fotovoltaik surya adalah satu, sedangkan faktor daya pembangkit listrik tenaga angin adalah 0,9. Integrasi kee mpat DG pada jaringan dis tribusi radial IEEE 71bus ditunjukkan pada Gambar 10. Selanjutnya dilakukan optimasi konfigurasi model jaringan dengan integrasi DG menggunakan metode SKB. Hasil optimasi ditunjukkan pada Gambar 11, Gambar 12, Gambar 13, Gambar 14, dan Tabel IV.

Gambar 11 menunjukkan fase perubahan kehilangan daya menjadi perubahan iterasi selama optimisasi jaringan distribusi radial IEEE 71-bus dengan integrasi empat DG. Variasi jumlah iterasi diterapkan untuk melihat performansi metode SKB dalam optimasi konfigurasi jaringan distribusi.

Dengan menggunakan variasi jumlah iterasi, diharapkan diperoleh informasi bahwa jumlah iterasi terendah untuk mendapatkan konfigurasi terbaik dan waktu komputasi terendah. Hasil optimasi menunjukkan bahwa terdapat 6 fase rugi daya akibat perubahan bilangan iterasi, yaitu masing masing 5, 10, 30, 50, 100, dan 200, seperti terlihat pada Gambar 11. Konfigurasi optimal diperoleh pada bilangan iterasi 200, yaitu perubahan fasa keenam, dengan waktu komputasi 232,87 detik. Dalam konfigurasi ini, posisi tie switch adalah masing-masing 5, 20, 42, 49, 60, 68, 70, 71, 73, 76, dan 79. Pada iterasi berikutnya, telah dihasilkan konfigurasi yang sama. Pada makalah ini telah dilakukan uji optimasi iterasi hingga 1000 iterasi, dan hasil optimal masih pada posisi tie switch yang sama. Konfigurasi optimal ini menghasilkan rugi daya sebesar $138,17 \mathrm{~kW}$, atau dengan kata lain penurunan rugi daya sebesar $40,01 \%$ dibandingkan dengan kehilangan daya sebesar $227,75 \mathrm{~kW}$ pada konfigurasi semula. Konfigurasi optimal dari model jaringan distribusi IEEE 71-bus ditunjukkan pada Gambar 13. Terlihat bahwa konfigurasi hasil optimasi jaringan distribusi dengan menggunakan metode SKB tetap berada pada topologi radial.

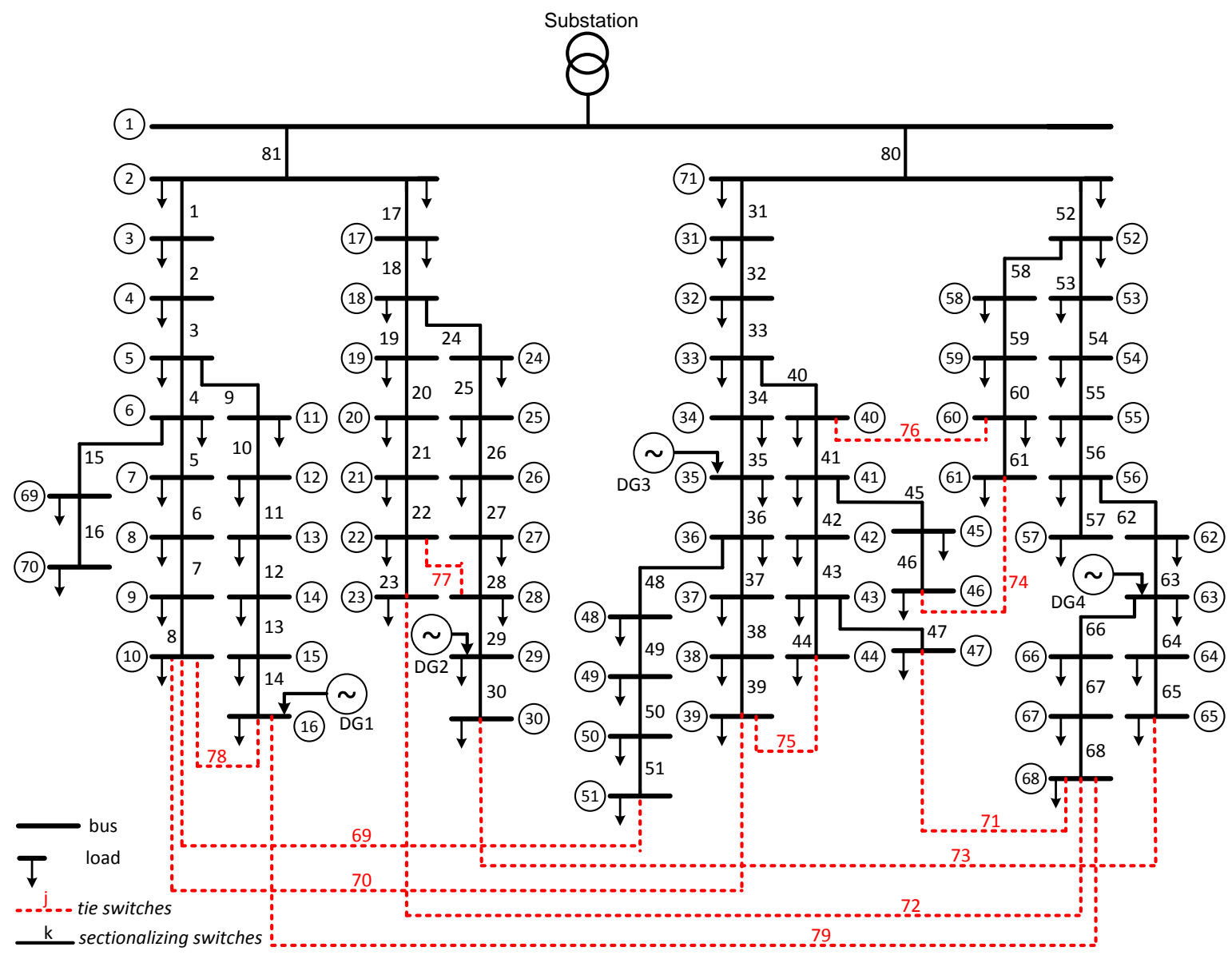

Gambar 10. Integrasi empat DG pada uji sistem jaringan distribusi radial IEEE 71 -bus 


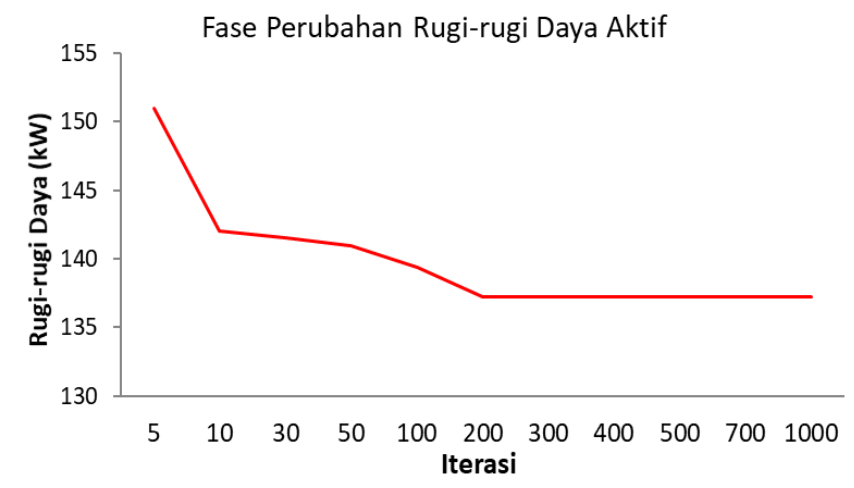

Gambar 11. Fase perubahan rugi-rugi daya aktif pada rentang iterasi saat proses optimisasi jaringan distribusi IEEE 71-bus dengan integrasi empat buah DG

Gambar 12 menunjukkan grafik dispersi kehilangan daya sistem uji distribusi IEEE 71-bus dalam kondisi pra rekonfigurasi tanpa DG, pasca rekonfigurasi tanpa DG, pra rekonfigurasi dengan DG, dan pasca rekonfigurasi dengan DG. Dapat dilihat pada Gambar 12 bahwa besarnya rugi daya akt if pada masing-masing cabang dikurangi dengan rekonfigurasi. Misalnya pada cabang 7, pada kondisi prakonfigurasi tanpa DG mengalami rugi daya aktif $12 \mathrm{~kW}$, namun setelah rekonfigurasi turun menjadi $10 \mathrm{~kW}$. Penurunan tersebut karena direkonfigurasi setelah arus yang mengalir pada konduktor 7 lebih kecil dari pada pra rekonfigurasi jaringan. Secara keseluruhan penurunan power loss jaringan distribusi tanpa integrasi DG pasca rekonfigurasi adalah $10,76 \%$, yang menurun dari $227,75 \mathrm{~kW}$ pada kondisi pra rekonfigurasi menjadi 205,86 kW pada kondisi pasca rekonfigurasi, seperti terlihat pada Tabel IV. Konfigurasi optimal diperoleh dengan menutup status tie switch 69, 72, 74, 75, 77, dan 78, sedangkan sectionalizing switch 5, 20, 42, 49, 60, dan 68 dalam keadaan terbuka.

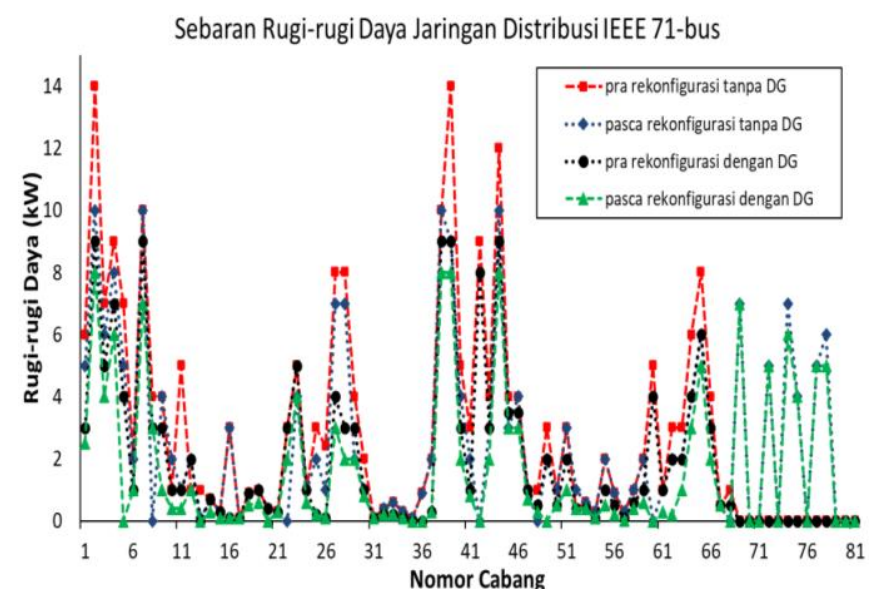

Gambar 12. Sebaran rugi-rugi daya aktif tiap bus pada uji sistem jaringan distribusi IEEE 71-bus

Integrasi DG pada bus 16, 29, 35, dan 63 dengan kapasitas masing-masing 0,3 MW, 0,2 MW, 0,1 MW, dan 0,4 MW berpengaruh signifikan terhadap pengurangan rugi daya aktif jaringan distribusi 71-bus, seperti pada gambar pada Gambar 12 dan Tabel IV.

Sebagai contoh, cabang 7 pada kondisi pra dan pasca rekonfigurasi jaringan tanpa DG memiliki rugi daya akt if masing-masing sebesar $12 \mathrm{~kW}$ dan $10 \mathrm{~kW}$, namun setelah integrasi DG berkurang menjadi $9 \mathrm{~kW}$. Penurunan tersebut disebabkan karena integrasi DG pada bus 16, 29, 35, dan 63 menyu mbang daya aktif dan reaktif dalam ju mlah yang cukup besar sehingga berpengaruh dalam meningkatkan besaran tegangan bus secara keseluruhan, dengan demikian arus yang mengalir pada penghantar jaringan distribusi menjadi berkurang. Total rugi daya jaringan distribusi menurun dari $227,75 \mathrm{~kW}$ menjadi $157,45 \mathrm{~kW}$. Selanjutnya konfigurasi jaringan yang optimal semakin mengurangi kehilangan daya menjadi 138,17 kW. Konfigurasi optimal diperoleh dengan me mbuat status tie switch 69, 72, 74, 75, 77, dan 78 ditutup, sedangkan sectionalizing switch 8, 22, 42, 48, 60, dan 68 menjadi terbuka.

Perbandingan profil tegangan jaringan distribusi model IEEE 71-bus pada kondisi pra rekonfigurasi tanpa DG, pasca rekonfigurasi tanpa DG, pra rekonfigurasi dengan DG, dan pasca rekonfigurasi dengan DG, ditunjukkan pada Gambar 14. Pengujian optimasi konfigurasi jaringan tanpa DG telah menghasilkan perbaikan profil tegangan pada hampir semua bus, kecuali pada bus 1, 2, 17, 52, dan 71. Pada bus tersebut besaran tegangan tetap berada pada nilai ideal yaitu 1 p.u. sesuai dengan nilai maksimum menahan diri dalam pengoptimalan ini. Pada bus 47 dan 48, terjadi sedikit penurunan besaran tegangan sebagai konsekuensi dari perubahan status sakelar. Seperti yang ditunjukkan pada hasil rekonfigurasi pada Gambar 14, terlihat bahwa bus 47 dan 48 terhubung ke lebih banyak bus, sehingga mengakibatkan sedikit penurunan tegangan.

Integrasi empat DG pada model jaringan distribusi IEEE 71-bus berpengaruh signifikan terhadap peningkatan profil tegangan bus dibandingkan dengan jaringan tanpa integrasi DG pada konfigurasi yang sama. Seperti terlihat pada Gambar 14, seluruh besaran tegangan bus mengalami kenaikan kecuali bus 1, 2, 17, 52, dan 71 yang telah mencapai 1 p.u. Secara keseluruhan profil tegangan yang meningkat secara signifikan dapat dilihat dari peningkatan besarnya tegangan terendah. Pada kondisi tanpa integrasi DG, tegangan terendah 0,900 p.u. pada bus 68, sedangkan pada kondisi dengan integrasi DG sebesar 0,933 p.u. pada bus 47 untuk konfigurasi jaringan yang sama, seperti terlihat pada Gambar 14 dan Tabel IV. Peningkatan ini terjadi akibat integrasi DG pada bus 16, 29, 35 , dan 63 yang menyumbang daya aktif dan reaktif cukup besar sehingga efek meningkatkan besaran keseluruhan dari tegangan bus. Secara khusus dapat diamati pada bus 68 . Besarnya tegangan pada bus merupakan tegangan terendah pada jaringan distribusi IEEE 71-bus pada kondisi awal yaitu 0,900 p.u. Integrasi DG4 dengan kapasitas $0,4 \mathrm{MW}$ pada bus 63 mampu meningkatkan besaran tegangan menjadi 0,939 p.u. Begitu pula dengan integrasi DG3 dengan kapasitas 0,1 MW pada bus 35 mampu menaikkan besaran tegangan dari 0,956 menjadi 1 p.u. 


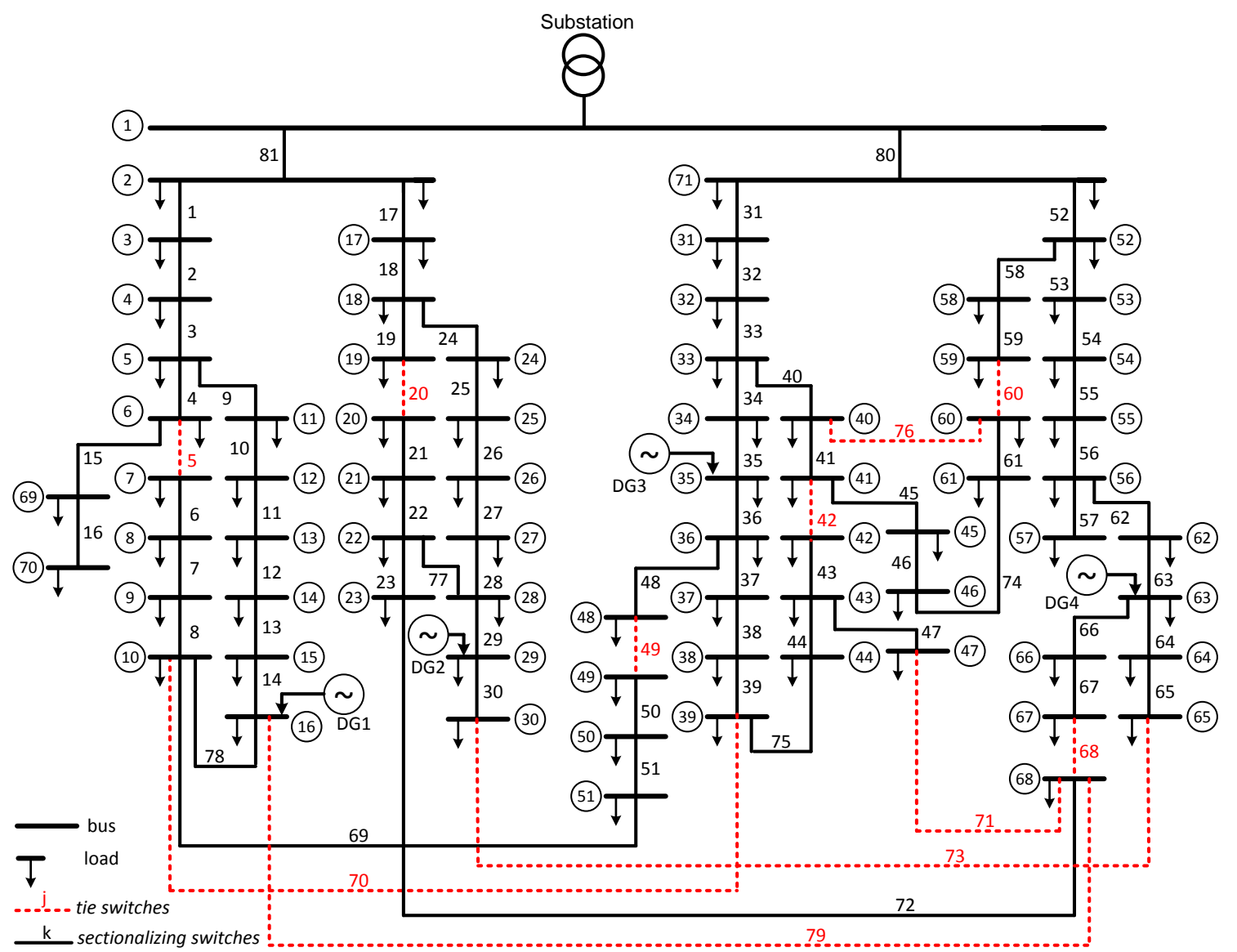

Gambar 13. Konfigurasi optimal pada jaringan distribusi radial IEEE 71-bus dengan integrasi empat buah DG

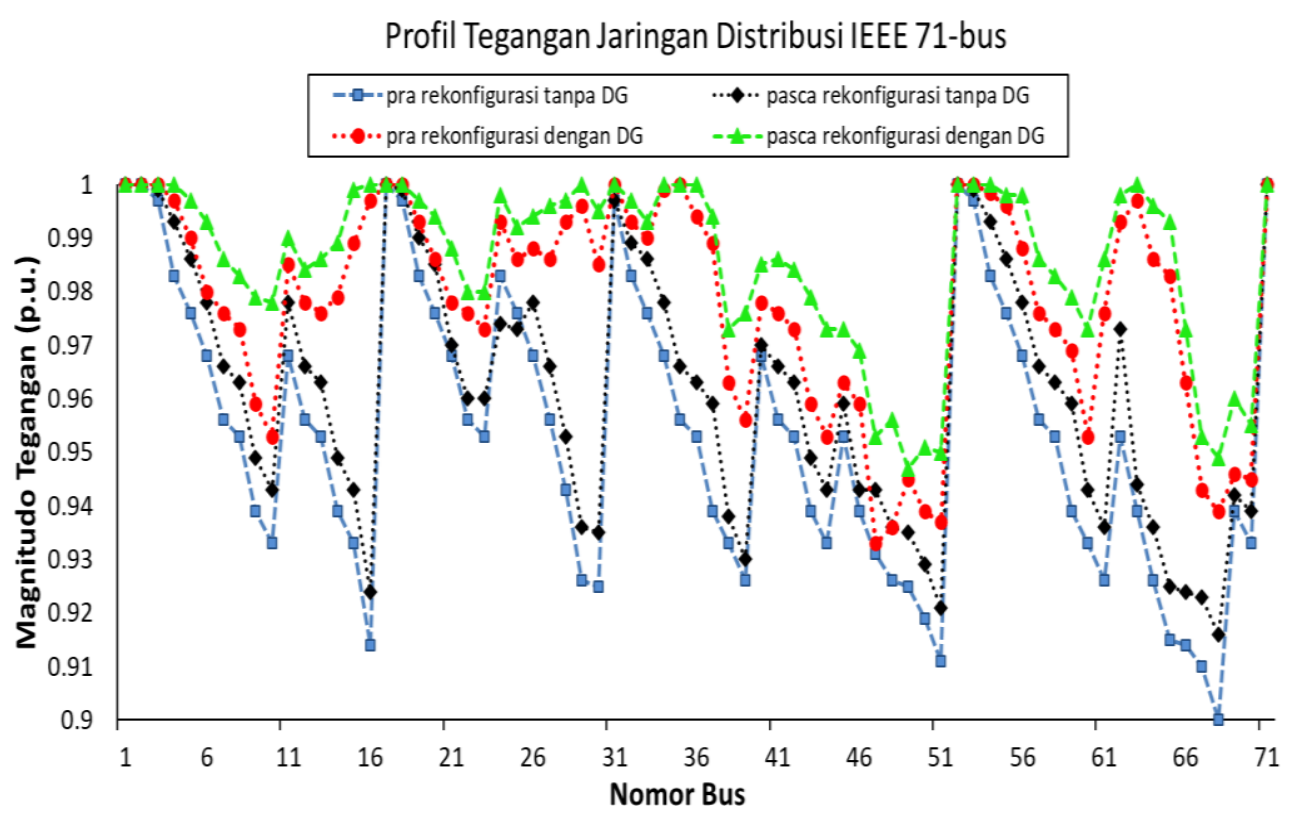

Gambar 14. Profil tegangan jaringan distribusi radial IEEE 71-bus 
TABEL IV. RESUME HASIL SIMULASI JARINGAN DISTRIBUSI RADIAL IEEE 71-BUS

\begin{tabular}{|c|c|c|c|c|c|c|c|}
\hline \multirow[b]{2}{*}{ Skenario Uji } & \multicolumn{7}{|c|}{ Parameter Analisis } \\
\hline & $\begin{array}{c}\text { Rugi-rugi } \\
\text { Daya Aktif } \\
\text { (kW) }\end{array}$ & $\begin{array}{c}\text { Prosentase } \\
\text { Rugi-rugi Daya } \\
\text { Aktif }(\%)\end{array}$ & $\begin{array}{c}\text { Efisiensi } \\
\text { Jaringan } \\
\text { Distribusi }(\%)\end{array}$ & $\begin{array}{l}\text { Tegangan } \\
\text { Minimum } \\
\text { (p.u.) }\end{array}$ & $\begin{array}{l}\text { Tegangan } \\
\text { Maksimum } \\
\quad \text { (p.u.) }\end{array}$ & $\begin{array}{l}\text { Nomor Tie } \\
\text { Switches } \\
\text { Ditutup }\end{array}$ & $\begin{array}{c}\text { Nomor } \\
\text { Sectionalizing } \\
\text { Switches } \\
\text { Dibuka }\end{array}$ \\
\hline $\begin{array}{l}\text { Pra rekonfigurasi } \\
\text { tanpa integrasi DG }\end{array}$ & 227,75 & Tidak ada & 95,34 & $\begin{array}{l}0,900 \\
\left(\mathrm{~V}_{68}\right)\end{array}$ & $\begin{array}{l}1,00 \\
\left(V_{1}\right)\end{array}$ & Tidak ada & Tidak ada \\
\hline $\begin{array}{l}\text { Pasca rekonfigurasi } \\
\text { tanpa integrasi DG }\end{array}$ & 205,86 & 10,76 & 95,99 & $\begin{array}{l}0,916 \\
\left(\mathrm{~V}_{68}\right)\end{array}$ & $\begin{array}{l}1,00 \\
\left(\mathrm{~V}_{1}\right)\end{array}$ & $\begin{array}{l}69 \\
72 \\
74 \\
75 \\
77 \\
78\end{array}$ & $\begin{array}{c}8 \\
22 \\
42 \\
48 \\
60 \\
68\end{array}$ \\
\hline $\begin{array}{l}\text { Pra rekonfigurasi } \\
\text { dengan integrasi DG }\end{array}$ & 157,45 & 31,98 & 96,12 & $\begin{array}{l}0,933 \\
\left(\mathrm{~V}_{47}\right)\end{array}$ & $\begin{array}{l}1,00 \\
\left(\mathrm{~V}_{1}\right)\end{array}$ & Tidak ada & Tidak ada \\
\hline $\begin{array}{l}\text { Pasca rekonfigurasi } \\
\text { dengan integrasi DG }\end{array}$ & 138,17 & 40,01 & 96,89 & $\begin{array}{l}0,947 \\
\left(\mathrm{~V}_{49}\right)\end{array}$ & $\begin{array}{l}1,00 \\
\left(\mathrm{~V}_{1}\right)\end{array}$ & $\begin{array}{l}69 \\
72 \\
74 \\
75 \\
77 \\
78\end{array}$ & $\begin{array}{c}5 \\
20 \\
42 \\
49 \\
60 \\
68 \\
\end{array}$ \\
\hline
\end{tabular}

Secara keseluruhan, profil tegangan pasca rekonfigurasi lebih baik daripada konfigurasi awal. Besaran tegangan terendah pra rekonfigurasi jaringan tanpa DG adalah 0,900 p.u. pada bus 68, sedangkan besaran tegangan terendah pasca rekonfigurasi adalah 0,916 p.u. di bus yang sama, seperti yang ditunjukkan pada Gambar 14 dan Tabel IV.

Selanjutnya profil tegangan jaringan distribusi ditingkatkan lebih lanjut dengan konfigurasi yang optimal. Hasil simulasi menunjukkan bahwa konfigurasi yang optimal mampu meningkatkan kualitas sistem distribusi tegangan yang dapat dilihat dari besarnya kenaikan tegangan terendah 0,933 p.u. pada bus 47 menjadi 0,953 p.u. pada bus yang sama. Peningkatan profil tegangan juga terjadi pada hampir semua bus kecuali pada bus yang besarnya tegangan 1 p.u. tercapai, seperti yang ditunjukkan pada Gambar 14. Meningkatkan profil tegangan dan mengurangi kehilangan daya memberikan kontribusi penting untuk meningkatkan efisiensi jaringan distribusi. Seperti terlihat pada Tabel IV bahwa efisiensi jaringan distribusi tanpa DG meningkat dari 95,34\% menjadi 95,99\% setelah rekonfigurasi optimal. Integrasi empat DG pada konfigurasi aslinya mampu meningkatkan efisiensi menjadi 96,12\%. Rekonfigurasi jaringan distribusi secara optimal dengan integrasi DG berhasil memaksimalkan efisiensi menjadi $96,89 \%$.

Optimisasi menggunakan metode SKB pada makalah ini menghasilkan performa jaringan distribusi yang meningkat secara signifikan. Sebagai perbandingan, uji sistem distribusi IEEE 33-bus sebagaimana digunakan dalam uji kasus pertama dalam makalah ini juga digunakan pada referensi [9]. Hasil yang dapat dibandingkan adalah rugi-rugi daya total yang dihasilkan pasca rekonfigurasi untuk kondisi jaringan distribusi original tanpa integrasi DG. Optimisasi jaringan distribusi IEEE 33-bus menggunakan metode harmony search algorithm pada referensi [9] menghasilkan rugi-rugi daya total $138,06 \mathrm{~kW}$, sedangkan optimisasi menggunakan metode SKB dalam makalah ini menghasilkan rugi-rugi daya total yang lebih kecil yaitu $129,65 \mathrm{~kW}$. Selanjutnya uji sistem distribusi IEEE 71-bus sebagaimana digunakan dalam makalah in i juga diterapkan dalam referensi [17]. Pada referensi [17], rekonfigurasi jaringan menggunakan metode fuzzy multiobjektif dan tabu search menghasilkan rugi-rugi daya total sebesar 224,63 kW, sementara pada makalah ini menggunakan metode SKB dihasilkan rugi-rugi daya total yang lebih kecil yaitu $205,86 \mathrm{~kW}$. Hasil ini menunjukkan bahwa optimisasi multi-objekt if menggunakan metode SKB lebih unggul dibandingkan dengan metode harmony search algorithm, fuzzy multi-objektif, dan tabu search.

\section{PENUTUP}

Pada makalah ini diusulkan metodologi rekonfigurasi jaringan distribusi radial yang optimal dengan integrasi DG menggunakan metode SKB. Metode tersebut dapat menemukan rekonfigurasi yang optimal untuk meningkatkan performa jaringan distribusi yang diuji. Dalam studi ini, metode SKB diuji pada jaringan distribusi IEEE 33-bus dan IEEE 71-bus. Berdasarkan hasil numerik, terlihat bahwa metode tersebut efektif dalam meningkatkan efisiensi kedua sistem uji jaringan distribusi. Efisiensi jaringan IEEE 33-bus pada pra rekonfigurasi tanpa DG, pasca rekonfigurasi tanpa DG, pra rekonfigurasi dengan DG, dan pasca rekonfigurasi dengan DG masing-masing adalah 94,79\%, 96,87\%, 98,93\%, dan 99,38\%. Untuk jaringan distribusi IEEE 71-bus, efisiensi pada kondisi pra rekonfigurasi tanpa DG, pasca rekonfigurasi tanpa DG, pra rekonfigurasi dengan DG, dan pasca rekonfigurasi dengan DG masing-masing adalah 95,34\%, $95,99 \%, 96,12 \%$, dan $96,89 \%$. Untuk profil tegangan jaringan, integrasi DG di kedua jaringan uji tersebut telah menghasilkan kualitas tegangan yang lebih baik. Kualitas tegangan lebih men ingkat lagi dengan merekonfigurasi jaringan yang optimal. 


\section{UCAPAN TERIMA KASIH}

Para penulis menyampaikan terima kasih yang sebesarbesarnya kepada Universitas Muhammadiyah Yogyakarta melalui Lembaga Penelitian, Publikasi, dan Pengabdian Masyarakat (LP3M) atas dukungannya dalam penelitian ini.

\section{REFERENSI}

[1] R. Syahputra, O. I. Pambudi, F. Mujaahid, and I. Soesanti, “A Study of Sugarcane Waste for Biomass Energy in the Supply of Electrical Energy", Joumal of Electrical Technology UMY, vol. 4, no. 1, pp. 28$38,2020$.

[2] N.C. Hien, N. Mithulananthan, and R. C. Bansal, "Location and Sizing of Distributed Generation Units for Loadabilty Enhancement in Primary Feeder”, IEEE System journal, vol. 7, no. 4, pp. 797-806, 2013.

[3] Y. Chai, L. Guo, C. Wang, Z. Zhao, X. Du, and J. Pan, "Network Partition and Voltage Coordination Control for Distribution Networks With High Penetration of Distributed PV Units", IEEE Transactions on Power Systems, vol. 33, no. 3, pp. 3396-3407, 2018.

[4] R. Syahputra, "Distribution Network Optimization Based on Genetic Algorithm", Joumal of Electrical Technology UMY, vol. 1, no. 1, pp. $1-9,2017$.

[5] F.C.R. Coelho, W. Peres, I.C.S. Júnior, and B.H. Dias, "Empirical continuous metaheuristic for multiple distributed generation scheduling considering energy loss minimisation, voltage and unbalance regulatory limits", IET Generation, Transmission \& Distribution, vol. 14, no.16, pp. 3301-3309, 2020.

[6] V. Calderaro, A. Piccolo, and P. Siano, "Maximizing DG penetration in distribution networks by means of GA based reconfiguration", Intemational Conference on Future Power Systems, Amsterdam, 2005.

[7] V. Farahani, B. Vahidi, and H.A. Abyaneh, "Reconfiguration and Capacitor Placement Simultaneously for Energy Loss Reduction Based on an Improved Reconfiguration Method", IEEE Trans. on Power Systems, vol.27, no.22,pp.587-595, 2012.

[8] Merlin and H. Back, "Search for a minimal-loss operating spanning tree configuration in an urban power distribution system", Proc. 5th PSCC Conference, Cambridge, U.K, pp. 1-18, 1975.

[9] R.S. Rao, S.V.L. Narasimham, M.R. Raju, and A.S. Rao, "Optimal Net work Reconfiguration of Large-Scale Distribution System Using Harmony Search Algorithm", IEEE Transaction on Power System, vol. 26, no. 3, pp. 1080-1088, 2011 .

[10] Augugliaro, L. Dusonchet, M. Ippolito, and E. R. Sanseverino, "Minimum Losses Reconfiguration of MV Distribution Networks Through Local Control of Tie-Switches", IEEE Transactions on Power Delivery, vol. 18, no. 3, pp. 762-771, 2003.

[11] B. Enacheanu, B. Raison, R. Caire, O. Devaux, W. Bienia, and N. Hadjsaid, "Radial Net work Reconfiguration Using Genetic Algorithm Based on the Matroid Theory", IEEE Transactions on Power Systems, vol. 23, no. 1, pp. 186-195, 2008.

[12] J. Bao, X. Liu, Z. Xiang, and G. Wei, "Multi-Objective Optimization Algorithm and Preference Multi-Objective Decision-Making Based on Artificial Intelligence Biological Immune System", IEEE Access, vol. 8, pp. 160221-160230, 2020.

[13] T. Niknam, H.Z. Meymand, and H.D. Mojarrad, "A practical multiobjective PSO algorithm for optimal operation management of distribution net work with regard to fuel cell power plants", Renewable Energy, vol.36,pp. 1529-1544, 2011.

[14] N.H. Ahmad, T.K.A. Rahman, and N. Aminuddin, "Multi-objective quantum-inspired Artificial Immune System approach for optimal net work reconfiguration in distribution system", Proceedings of IEEE Conf. on Power Engineering and Optimization Conference (PEOCO), Melaka, Malaysia, 2012.

[15] E.G. Carrano, F.G. Guimaraes, R.H.C. Takahashi, O.M. Neto, and F Campelo, "Electric Distribution Network Expansion Under LoadEvaluat ion Uncertainty Using an Immune System Inspired Algorithm", IEEE Transactions on Power Systems, vol. 22, no. 2, pp. 851-861, 2007.

[16] J. Mendoza, R. Lopez, D. Morales, E. Lopez, P. Dessante, and R. Moraga, "Minimal loss reconfiguration using genetic algorithms with restricted population and addressed operators", IEEE Trans. on Power Systems, vol. 21, no. 2, pp. 948-954, 2006.

[17] N. Rugthaicharoencheep and S. Sirisumrannukul, "Optimal feeder reconfiguration with distributed generators in distribution system by fuzzy multiobjective and Tabu search", International Conference on Sustainable Power Generation and Supply, Nanjing, China, 2009.

[18] Y. J. Jeon, J. C. Kim, J. O. Kim, J. R. Shin, and K. Y. Lee, “An Efficient Simulated Annealing Algorithm for Network Reconfiguration in Large-Scale Distribution Systems", IEEE Trans. on Power Delivery, vol. 17, no. 4, pp. 1070-1078,2002.

[19] H. Falaghi, M.R. Haghifam, and C. Singh, "Ant Colony OptimizationBased Method for Placement of Sectionalizing Switches in Distribution Networks Using a Fuzzy Multiobjective Approach", IEEE Trans on Power Delivery, vol. 24, no. 1, pp. 268-276, 2009.

[20] R. Syahputra, I. Robandi, and M. Ashari, "Optimization of Distribution Network Configuration with Integration of Distributed Energy Resources Using Extended Fuzzy Multi-objective Method", Intemational Review of Electrical Engineering (IREE), vol. 9, no.3, pp. 629-639, 2014.

[21] J. Li, Z.M. Liu, C. Li, and Z. Zheng. "Improved artificial immune system algorithm for Type-2 fuzzy flexible job shop scheduling problem", IEEE Transactions on Fuzzy Systems, vol. 2020.

[22] A. Abid, M.T. Khan, and M.S. Khan. "Multidomain Features-Based GA Optimized Artificial Immune System for Bearing Fault Detection", IEEE Transactions on Systems, Man, and Cybernetics: Systems, vol. 50, no. 1 , pp. 348-359, 2020.

[23] S. S.D. Xu, H.C. Huang, Y.C. Kung, and Y.Y. Chu. "A Networked Multirobot CPS with Artificial Immune Fuzzy Optimization for Distributed Formation Control of Embedded Mobile Robots", IEEE Transactions on Industrial Informatics, vol. 16, no. 1, pp. 414-422, 2020.

[24] Ł. Śladewski, and K. Świrski. "Optimization of a Coal Fired Boiler Using Artificial Immune System", IEEE 6th Intemational Conference on Energy Smart Systems (ESS), Kyiv, Ukraine, 17-19 April, 2019.

[25] D. Chen and F. Zhang. "5G Message Service System Based on Artificial Immune Dynamic Adaptive Mechanism", IEEE Access, vol. 7,pp. 91146-91159, 2020.

[26] A. Azizivahed, A. Arefi, S. Ghavidel, M. Shafie-khah, L. Li, J. Zhang, and J.P.S. Catalão. "Energy Management Strategy in Dynamic Distribution Net work Reconfiguration Considering Renewable Energy Resources and Storage", IEEE Transactions on Sustainable Energy, vol. 11, no. 2, pp. 662-673, 2020.

[27] B. Singha and B.J. Gyanish. "Impact assessment of DG in distribution systems from minimization of total real power loss viewpoint by using optimal power flow algorithms", Energy Reports, vol. 4, pp. 407-417, 2018.

[28] I. Dutt, S. Borah, and I.K. Maitra. "Immune System Based Intrusion Detection System (IS-IDS): A Proposed Model”, IEEE Access, vol. 8, pp. 34929-34941,2020.

[29] C.C.B. Fioravanti, T.M. Centeno, and M.R. Delgado. "A Deep Artificial Immune System to Detect Weld Defects in DWDI Radiographic Images of Petroleum Pipes", IEEE Access, vol. 7, pp. 180947-180964,2020.

[30] F.T.S. Silva, L.R. Araujo, and D.R.R. Penido, "Optimal Substation Placement in Distribution Systems using Artificial Immune Systems", IEEE Latin America Transactions, vol. 16, no. 2, pp. 505-513, 2018.

[31] Y. Wang, Y. Xu, J. Li, J. He, and X. Wang. "On the Radiality Constraints for Distribution System Restoration and Reconfiguration Problems", IEEE Transactions on Power Systems, vol. 35, no. 4, pp. 3294-3296, 2020.

[32] Z. Yin, X. Ji, Y. Zhang, Q. Liu, and X. Bai. "Data-driven approach for real-time distribution network reconfiguration", IET Generation, Transmission \& Distribution, vol. 14, no. 13, pp. 2450-2463,2020.

[33] M.A. Muhammad, H. Mokhlis, K. Naidu, A. Amin, J.F. Franco, and M. Othman. "Distribution Network Planning Enhancement via Network Reconfiguration and DG Integration Using Dataset Approach and Water Cycle Algorithm", Joumal of Modern Power System s and Clean Energy, vol. 8, no. 1, pp. 86-93, 2020. 